Ewa M. Boryczka*

\title{
Partycypacyjne instrumenty zarządzania jednostkami samorządu terytorialnego
}

\section{Samorząd a społeczność lokalna - wprowadzenie}

Związek jednostek samorządu terytorialnego ze społecznością lokalną jest istotą samorządności, gdyż wyrasta ona z pojęcia społeczności lokalnej, która odgrywa główną rolę i jest gospodarzem przestrzeni terytorialnej. Samorząd terytorialny jest jednym $\mathrm{z}$ ważnych elementów funkcjonowania systemu demokratycznego (Tocqueville, 1996, za: Swaniewicz, 2008, s. 67). Sprawnie funkcjonujący samorząd definiowany jest jako wspólnota połączona silnymi więzami i interakcjami między członkami tej wspólnoty, a wybieralna w wyborach powszechnych władza wyposażona w szereg instrumentów działa w imieniu społeczności lokalnej, jednocześnie na nią oddziałując. Stąd też sprawnie i zdrowo funkcjonujący system demokratyczny zakłada bliskość między władzą lokalną a społecznością (Sakowicz, 2007, s. 44). Wskazuje się także, że instytucje rządowe w systemie demokratycznym bez instytucji samorządowych nie mogą posiadać ducha swobody, a nawet ducha prawdziwej wolności, która jest fundamentem demokracji. Z kolei bez instytucji samorządowych, które działają w bliskości ze społecznościami lokalnymi, wcześniej czy później ujawniają się silne tendencje despotyczne, które są wpisane w samą naturę systemów społecznych. W takim przypadku silnie się one uaktywniają, wypaczając i niszcząc systemy demokratyczne. Potrzeba samorządności wynika więc z samej istoty życia społecznego (Swianiewicz, 2008, s. 67).

Należy w tym miejscu zadać pytanie o rolę i wartości związanie z istnieniem samorządów w państwach demokratycznych? Idea funkcjonowania samorządu

* Uniwersytet Łódzki, Wydział Ekonomiczno-Socjologiczny, Instytut Gospodarki Przestrzennej, Katedra Gospodarki Regionalnej i Środowiska, 90-214 Łódź, Rewolucji 1905 r. nr 39. 
terytorialnego związana jest z jedną z najważniejszych wartości demokracji, czyli wolnością (autonomią). Rolą samorządów jest zapobieganie koncentracji władzy publicznej w jednych rękach, a także zwiększanie możliwości podejmowania własnych decyzji politycznych w mniejszych społecznościach lokalnych. Ponadto samorządy mają za zadanie zwiększać zaangażowanie innych jednostek i podmiotów funkcjonujących na danym obszarze w proces samorządzenia. Z założenia także dzięki istnieniu samorządów i przedstawicieli społeczności lokalnej, którzy w nich zasiadają, zwiększa się dostęp obywateli do rządzących (osób podejmujących kluczowe decyzje). Ponadto istnieje możliwość wpływania także na ich decyzje oraz zwiększa się stopień poinformowania społeczności o działaniach władzy. Wskazane wartości i elementy mają więc większe znaczenie w zdecentralizowanym systemie demokratycznym niż w przypadku systemu opartego na centralnym rządzeniu państwem.

Decentralizacja systemu demokratycznego, a także nowoczesne, sprawne i efektywne zarządzanie strategiczne $\mathrm{w}$ jednostkach samorządu terytorialnego wymaga większego niż dotychczas zaangażowania społeczności lokalnej. Wskazuje się, że zarządzanie strategiczne powinno być jasne, przejrzyste i zrozumiałe dla społeczności lokalnej, a także powinno być realizowane w poczuciu uczciwości oraz równych szans rozwoju wszystkich grup społecznych. Istotnym elementem jest również uwzględnienie interesów różnych grup społecznych, co zachęca do ich współdziałania (zasada partycypacji), a także ważną rolę odgrywa dążenie do zaspokajania potrzeb społeczności lokalnej (zasada społecznego nastawienia) (Markowski, Marszał, 2005, s. 13).

W wielu dyskusjach nad możliwościami i przyszłością rozwoju instytucji obywatelskich, które odgrywają coraz większą rolę w procesie zarządzania m.in. jednostkami samorządu terytorialnego, pojawia się pojęcie demokracji deliberacyjnej. To pojęcie występuje również w dyskusjach nad rolą i znaczeniem społeczności lokalnej w procesie współdecydowania w zarządzaniu. Demokracja deliberacyjna ma za zadanie prowadzić w niedalekiej przyszłości do rozwoju i upowszechnienia bardziej zaawansowanych form procesu komunikacji w demokratycznych społeczeństwach. Deliberację definiuje się jako „publiczny proces komunikacji zorientowanej na poszukiwanie wystarczająco dobrych argumentów przemawiających za określonymi ocenami oraz rozwiązaniami dyskutowanych kwestii i odnoszących się do istotnych problemów wspólnoty". Stosowanym narzędziem w deliberacji jest perswazja ${ }^{1}$, a jej celem jest dążenie do osiągnięcia konsensusu, ale wskutek reinterpretacji potrzeb, zmiany postaw i preferencji komunikujących się stron. Zwolennicy podkreślają wyższość deliberacyjnych form dialogu i partnerstwa społecznego, obywatelskiego od dotychczasowych form demokracji, w której najczęściej dominują trójstronne reprezentacje oraz klasycz-

1 Perswazja, czyli namawianie do czegoś lub odradzanie czegoś z przytoczeniem odpowiednich argumentów (Stownik języka polskiego, www.sjp.pwn.pl). 
ne formy komunikacji, umożliwiające agregację, artykulację, a następnie osiągnięcie konsensusu interesów zaangażowanych grup społecznych. Demokracja deliberacyjna i stosowane w niej formy prowadzą do aktywizacji obywatelskiej, wzmocnienia poczucia wspólnoty, zmiany poglądów, postaw, preferencji komunikujących się ze sobą stron. W ten sposób wypracowywany jest zupełnie inny sposób spojrzenia i budowania wartości dóbr wspólnych, którymi dysponuje dana wspólnota (Cohen, Cooke, 1996, za: Sroka, Kwieciński, 2007, s. 3-5).

Zakłada się, że istotną rolę w drodze do demokracji deliberacyjnej odegrają stosowane obecnie metody i techniki partycypacyjne, które mogłyby być stopniowo uzupełniane o innych przedstawicieli społeczności lokalnych (m.in. organizacje pozarządowe). Aby jednak tak się stało, konieczne jest wypracowanie i przyswojenie nowych kodów komunikacyjnych i zmian w komunikacji społecznej i politycznej w Polsce. Ta zdolność do zmiany postaw, preferencji oraz stylu i treści komunikacji wydaje się być kluczowym czynnikiem na drodze do demokracji deliberacyjnej, którą charakteryzuje wielopodmiotowa komunikacja deliberacyjna, a z kolei jej przedmiotem są wyzwania rozwojowe stojące przed wspólnotą samorządową. Jednym z takich wyzwań jest zarządzanie strategiczne z szerokim wykorzystaniem partycypacji społecznej.

\section{Partycypacja społeczna w zarządzaniu jednostkami samorządu terytorialnego}

\subsection{Partycypacja społeczna - idea, istota, cele}

Partycypacja społeczna jest zagadnieniem budzącym zainteresowanie oraz wiele emocji. Emocje z nią związane wynikają z nadziei, ale także z wielu obaw.

W życiu jednostki samorządu terytorialnego jednym z przejawów aktywności społecznej jej mieszkańców jest uczestnictwo (partycypacja) w funkcjonowaniu tej wspólnoty terytorialnej.

W historii powiązanie partycypacji z demokratyczną obywatelskością ma naturalne korzenie. Jednak na przestrzeni dekad zarówno postulowany, jak i praktykowany zakres partycypacji był bardzo zróżnicowany. Po drugiej wojnie światowej partycypacja społeczna uważana była wręcz za niebezpieczną dla demokracji. Zmiana tego spojrzenia nastąpiła w latach 60. XX w. i trwa do dziś, z coraz większym naciskiem na jej pozytywne oddziaływanie i związek z demokratyczną obywatelskością. Jednak zwolenników i przeciwników nie brakuje. Wciąż bez odpowiedzi pozostaje pytanie, ile partycypacji w demokracji, a argumentów za i przeciw wydaje się sporo, choć z punktu widzenia teorii partycypacja wydaje się być jednym z trzech podstawowych elementów obywatelskości. 
W tym kontekście partycypacja oznacza prawo do pełnego i równego uczestniczenia w gospodarce i procesach sprawowania władzy w samorządzie lokalnym.

W tradycyjnym ujęciu partycypacja oznacza udział mieszkańców w formułowaniu, podejmowaniu decyzji i realizacji polityki, co zarezerwowane było dotąd do wyłącznej kompetencji władzy samorządowej i administracji (Podręcznik zarzadzania partycypacyjnego, s. 7). W rzeczywistości dotyczy ona jednak decyzji, które podejmowane są ostatecznie nie przez mieszkańców biorących w nich udział, a przez osoby mające demokratyczną legitymizację władzy, ale z ich mniejszym lub większym zaangażowaniem (Parry, Moyser, Day, za: Swianiewicz, Klimska, Mielczarek, 2004, s. 35-38). Termin ,uczestnictwo mieszkańców” podkreśla rolę raczej grup mieszkańców niż jednostek. $\mathrm{Z}$ reguły są to grupy reprezentujące podobne stanowiska, interesy, działalność czy też organizowane wokół wspólnego miejsca zamieszkania. W praktyce partycypacja wymaga nie tylko aktywnego udziału tych grup, ale także aktywności poszczególnych jednostek będących ich reprezentantami. Grupy te mogą reprezentować różne interesy lokalne, którymi się kierują. Mają one najczęściej charakter formalny, ale mogą występować też jako grupy nieformalne, manifestujące sprzeciw w określonych sprawach.

$\mathrm{W}$ tradycyjnym ujęciu i w tradycyjnym modelu funkcjonowania samorządu (ang. local government) dominują formalne, zhierarchizowane procedury i instytucje, których przejawami partycypacji społecznej są takie działania, jak: lobbowanie, pisemne zgłaszanie uwag, petycje do władz, pisanie listów i stanowisk, demonstracje oraz uczestnictwo w spotkaniach $\mathrm{z}$ władzami i przedstawicielami administracji. W tym modelu zarządzania partycypacja oznacza branie udziału w formułowaniu, podejmowaniu decyzji i realizacji polityki publicznej. Partycypacja dotyczy udziału mieszkańców, którzy próbują oddziaływać na decyzje i działania samorządu lokalnego. Jednak decyzje te ostatecznie podejmowane są przez osoby mające demokratyczną legitymizację (np. prezydenta, wójta, radnych). W literaturze przedmiotu podkreśla się różnice między głosem rozumianym jako możliwość wyrażenia swojego stanowiska, która przysługuje aktywnym politycznie członkom społeczności lokalnej, a głosem pozostałych członków tej społeczności, który rozumiany jest jako udział w głosowaniu podczas wyborów. Głos ten jednak w okresie między jednymi a drugimi wyborami niewiele znaczy, gdyż należy on tylko do demokratycznie wybranych przedstawicieli społeczności (Swaniewicz, Klimska, Mielczarek, 2004, s. 35-42).

W nowoczesnym ujęciu partycypacja w zarządzaniu jednostkami samorządu terytorialnego oznacza nie tylko udział różnych grup społeczności lokalnych w formułowaniu polityk publicznych czy też strategii, ale także, a może przede wszystkim, udział tych grup w podejmowaniu decyzji i realizacji zbudowanej wspólnie polityki publicznej. W procesie zarządzania lokalnego (ang. local governance) charakterystyczny staje się elastyczny model podejmowania decyzji oparty na luźnych powiązaniach poziomych między różnymi podmiotami ze sfery publicznej, prywatnej i społecznej. Fundamentem działania samorządu lokalnego 
staje się tworzenie dobrego klimatu do dobrowolnej współpracy różnych podmiotów i aktorów życia społeczno-gospodarczego, co służyć ma realizacji wspólnie określonych celów. Nie jest to już więc bezpośrednie podejmowanie przez władze samorządowe decyzji w oparciu o uprawnienia władcze i legitymizację władzy (ang. power over), a bardziej skoncentrowanie działań na umiejętności mobilizacji zasobów lokalnych (kapitału społecznego, ludzkiego, finansowego, instytucjonalnego itp.) w celu osiągnięcia wspólnie wyznaczonych celów (ang. power to) (Swianiewicz, Klimska, Mielczarek, 2004, s. 25). Partycypacja oznacza zatem udział członków społeczności lokalnej w procesach decyzyjnych lub w korzystaniu z ekonomicznych efektów organizacji. Jest ona o tyle istotna, że jest formą dialogu społecznego $\mathrm{w}$ jednostce samorządu terytorialnego oraz traktowana jako zinstytucjonalizowany środek rozwiązywania konfliktów społecznych (Gawroński, 2007, s. 145). Coraz szerszy udział społeczności lokalnej w zarządzaniu strategicznym w jednostkach samorządu terytorialnego związany jest ze zmianą społecznej struktury organizacji. Staje się ona mniej sztywnym i zhierarchizowanym układem, z charakterystycznym podziałem na władzę i podwładnych (kierujących i kierowanych) i zmierza coraz bardziej w kierunku partnerskiej współpracy wielu podmiotów sektora publicznego, prywatnego i społecznego.

W takim ujęciu jednostka samorządu terytorialnego realizuje swoje cele, koncentrując się na współpracy ze społecznością lokalną, a dzięki temu osiąga legitymizację partnerstwa poprzez rezultaty (ang. output legitimacy). Nowoczesne zarządzanie $\mathrm{w}$ jednostkach samorządu terytorialnego i zawierane partnerstwa między różnymi aktorami życia społeczno-gospodarczego wymagają nie tylko klasycznych już konsultacji, ale rzeczywistego udziału różnych podmiotów w kreowaniu rozwiązań i działań. Szczególne znaczenie zyskuje w ostatnim czasie partycypacja określana mianem „decyzyjnej”, która traktowana jest jako forma społecznego dialogu w organizacji oraz zinstytucjonalizowany środek rozwiązywania konfliktów społecznych. Partycypacja decyzyjna wiąże się zatem $\mathrm{z}$ istotną zmianą społecznej struktury organizacji samorządu terytorialnego, która polega na odejściu od tradycyjnego i sztywnego podziału na kierujących i kierowanych i dążeniu do partnerskich relacji między poszczególnymi aktorami życia społeczno-gospodarczego. Aktorzy życia społeczno-gospodarczego wspólnoty nie będą oczekiwali więc jedynie udziału w mało zobowiązujących konsultacjach, które w niewielkim stopniu aktywizują pozostałych partnerów. Oferując merytoryczny, a także niejednokrotnie finansowy udział w realizacji polityki, oczekują posiadania realnego wpływu na podejmowane decyzje. $Z$ tego punktu widzenia w literaturze przedmiotu wskazuje się dwa typy uczestników, którzy mogą mieć wpływ na podejmowanie decyzji w procesie zarządzania jednostkami samorządu terytorialnego. Są to:

a) mieszkańcy i ich organizacje, co powoduje, że udział w polityce mają zarówno poszczególni mieszkańcy, jak i organizacje pozarządowe reprezentujące interesy wybranych grup społeczności lokalnej; 
b) kluczowi aktorzy życia społecznego, tacy jak przedsiębiorcy, przedstawiciele sfery badawczo-rozwojowej i edukacyjnej, instytucje otoczenia biznesu, instytucje publiczne.

Partycypacja społeczna oparta jest na partnerskiej współpracy między członkami społeczności lokalnej a sprawującymi władzę przedstawicielami tej społeczności, wybieranymi w wyborach powszechnych. W efekcie tej współpracy uzyskuje się trafniejszy, bardziej uwzględniający potrzeby mieszkańców obraz rzeczywistości i efektywniejsze metody rozwiązywania lokalnych problemów, akceptację realizowanych przez samorząd działań, a także zmniejsza się prawdopodobieństwo występowania konfliktów. Ponadto partycypacja sprzyja edukacji obywatelskiej, budowaniu identyfikacji mieszkańców ze wspólnotą samorządową i miejscem, budowaniu tożsamości lokalnej i obywatelskiej, a także zwiększa rzeczywistą kontrolę mieszkańców nad władzą samorządową.

Partycypacja społeczna w zarządzaniu realizować ma konkretne cele, które można podzielić na trzy główne grupy. Pierwszą grupę stanowią cele o charakterze psychologicznym, związane z rozwojem indywidualnym członków społeczności lokalnej. Należy do nich proces samorealizacji i humanizacji pracy, poprawa motywacji, poczucie godności, autonomii oraz przynależności do grupy. Drugą grupę stanowią cele o charakterze społeczno-politycznym, które związane są z poprawą klimatu społecznego i redukcją konfliktów społecznych we wspólnocie terytorialnej, wzrostem poziomu identyfikacji mieszkańców ze wspólnotą, a także związane są ze zwiększeniem poziomu demokratyzacji zarządzania w jednostkach samorządu terytorialnego. Trzecią grupę stanowią cele o charakterze ekonomicznym, związane z rozwojem kreatywności i efektywności oraz większym zaangażowaniem uczestników procesu partycypacyjnego. Poprzez realizację tego celu następuje wzrost wartości zasobów lokalnych, co przyczynia się również do wzrostu korzyści dla członków danej społeczności, w tym pracowników urzędów i jednostek organizacyjnych jednostki samorządu terytorialnego (Kot, 2003, s. 227-233; Gawroński, 2007, s. 124).

Korzyści wynikających procesu partycypacji społecznej, czyli zudziału społeczności lokalnej w życiu publicznym wspólnoty terytorialnej, jest bardzo wiele. Nie są to jednak jedynie korzyści dla jednostki samorządu terytorialnego. Każdy z uczestników procesu partycypacji powinien zyskać w wyniku swojego w nim udziału.

$\mathrm{W}$ procesie partycypacji działania publiczne realizowane przez jednostki samorządu terytorialnego stają się bardziej zrozumiałe dla mieszkańców, a wskutek poznania i zrozumienia ich potrzeb samorząd może lepiej odpowiadać na te potrzeby. Mieszkańcy dzięki prowadzonej kampanii informacyjnej są lepiej poinformowani o planach i zamierzeniach samorządu. Mają także możliwość poznania tych planów na wczesnym etapie procesu decyzyjnego, co ułatwić może skuteczne wstrzymanie lub poparcie działań samorządu.

W toku współpracy między podmiotami sektora publicznego, prywatnego i społecznego oraz samych mieszkańców zwiększa się możliwość uzyskania no- 
wych i niekonwencjonalnych rozwiązań dla wielu zidentyfikowanych we wspólnocie problemów. Wynikiem tego jest precyzyjniejsze określenie priorytetów i lepsze, bardziej efektywne dysponowanie posiadanymi zasobami, aby zrealizować cele. Organizacje społeczne, przedsiębiorcy definiują problemy społeczne, gospodarcze danej jednostki samorządowej i sami przedstawiają sposoby ich rozwiązania. Dzięki temu powstaje mapa czy profil problemu publicznego, który powinien zostać rozwiązany jako ten, który jest najbardziej dokuczliwy dla społeczności lokalnej. W wyniku tej współpracy następuje zwiększenie prawdopodobieństwa wypracowania trafnych działań mających na celu rozwiązanie zidentyfikowanych problemów. Następuje także szybszy przepływ informacji między społecznością lokalną a samorządem lokalnym o pojawiających się problemach, zanim urosną do znacznych rozmiarów.

Stąd też organizacje pozarządowe czy też przedsiębiorcy traktowani są w procesie partycypacji społecznej jako dostarczyciele szczegółowej wiedzy eksperckiej w zakresie dziedzin swojego funkcjonowania.

Współcześnie mieszkańcy poznają zasady działania samorządów, stają coraz lepiej wykształceni, świadomi swoich praw i interesów, a także stają się bardziej aktywni w obronie własnych partykularnych oraz wspólnych interesów. Dzięki częstemu informowaniu i komunikowaniu się samorządu ze społecznością lokalną władze samorządowe budują klimat zaufania, co wpływa także na społeczną legitymizację ich decyzji. Jednocześnie w procesie partycypacji zwiększa się rzeczywista kontrola nad władzą samorządową.

W procesie partycypacji społecznej dzięki możliwości artykułowania własnych potrzeb, oczekiwań i problemów, a także dzięki wspólnemu ich rozwiązywaniu następuje budowanie i wzmacnianie identyfikacji społeczności z jednostką samorządu terytorialnego i z podejmowanymi działaniami. Uwzględnienie przez władze samorządowe postulatów, interesów artykułowanych przez uczestników procesu partycypacji powoduje wzrost wśród mieszkańców, przedsiębiorców poczucia wpływu i współodpowiedzialności za podejmowane działania. Partycypacja społeczna przyczynia się również do rozwoju społecznego uczestników tego procesu, zdobywania nowej wiedzy i doświadczeń, co wzmacnia zaangażowanie w sprawy jednostki samorządu terytorialnego (Swianiewicz, Klimska, Mielczarek, 2011, s. 35-42).

W toku wzajemnego poznawania się różnych grup i interesów poszczególnych członków społeczności lokalnej widoczne jest ograniczenie konfliktów w tych wspólnotach, a także nawiązywanie nowych kontaktów i budowanie kapitału relacyjnego, który sprzyja wzmacnianiu współpracy między tymi grupami.

Aktywnie uczestniczące w procesie partycypacji grupy przedsiębiorców, organizacji pozarządowych poprawiają swój wizerunek i pozycję na rynku.

Dla poszczególnych jednostek (mieszkańców) uczestniczących w tym procesie aktywny udział jest lekarstwem na alienację w społeczności lokalnej. To doświadczenie pozwala mieć poczucie wpływu na otaczającą rzeczywistość 
i wolności, a także nabrać pewności siebie poprzez kontrolę nad własnym życiem i wspomnianą wcześniej rzeczywistością.

Ponadto $\mathrm{w}$ procesie partycypacji rozwijane są postawy i umiejętności obywatelskie mieszkańców, co wpływa na proces zarządzania, czyniąc go bardziej demokratycznym. Mówi się nawet, że partycypacja jest rzeczywistą koniecznością, gdyż we współczesnym świecie i we współczesnym społeczeństwie niemożliwe jest rządzenie, a tym bardziej współrządzenie bez przyzwolenia i aktywności rządzonych (Roberts, 2008).

\subsection{Zakres i formy procesu partycypacji}

Zakres i intensywność procesu partycypacji społecznej, czyli udziału społeczności lokalnej w podejmowaniu decyzji w samorządach lokalnych, są bardzo zróżnicowane i mają związek z realizowanymi stylami zarządzania. W zależności od zakładanego zakresu wyróżniamy różne formy partycypacji społecznej (informowanie, konsultowanie, współdecydowanie). Jedną z form jest informowanie. Polega ono na przekazywaniu mieszkańcom informacji o decyzjach, procedurach podejmowanych przez administrację. Potrzeba posiadania pełnej i rzetelnej informacji jest podstawą procesu uspołecznienia politycznego i decyzyjnego. Bez informacji mieszkańcy nie są w stanie skutecznie partycypować w sprawach publicznych. Jest to relacja jednokierunkowa między władzą a społecznością lokalną. Informowanie może być bierne, gdzie administracja umożliwia mieszkańcom dostęp do informacji, oraz aktywne, gdy samorząd podejmuje aktywne działania w celu dotarcia z informacjami do członków lokalnej społeczności (promocja, ogłoszenia, spotkania itp.).

Drugą formą partycypacji społecznej jest konsultowanie, które ma charakter dwustronny między administracją i mieszkańcami. Przebieg konsultowania jest następujący: samorząd proponuje rozwiązania i zbiera opinie na ich temat, które w mniejszym lub większym stopniu uwzględnia w docelowych rozwiązaniach. W ten sposób obie strony dialogu społecznego poznają swoje stanowiska, ale podkreślić trzeba, że przedstawiciele samorządu nie są zobowiązani do uwzględniania uzyskanych opinii i uwag. Konsultowanie wymaga więcej czasu niż informowanie.

Trzecią formą partycypacji jest współdecydowanie, w którym administracja nie tylko zasięga opinii. We współdecydowaniu chodzi o partnerstwo przy wspólnym budowaniu rozwiązań. Tutaj władze samorządowe razem z innymi aktorami życia społeczno-gospodarczego wspólnie definiują problemy i szukają najlepszych rozwiązań. Komunikacja w procesie współdecydowania zachodzi przez cały czas identyfikowania problemów poprzez budowanie i realizację konkretnych rozwiązań. We współdecydowaniu fundamentem jest uznanie zasady partnerstwa we wzajemnych relacjach administracji i społeczności lokalnej. Współdecydo- 
wanie ma charakter znacznie mniej hierarchiczny od pozostałych form, jakimi są konsultowanie i informowanie. Najbardziej zaawansowaną i rozwiniętą formą współdecydowania jest delegowanie części uprawnień i zadań do realizacji na rzecz partnerów uczestniczących w tym procesie.

Udział poszczególnych grup uczestników procesu partycypacji jest oczywiście zróżnicowany i zależny od wielu czynników. Partycypacja społeczna w jednostkach samorządu terytorialnego może właściwie nie występować (brak udziału społeczności lokalnej w procesie decyzyjnym) i taka sytuacja ściśle związana jest z zamkniętym, autokratycznym (styl nieinteraktywny) stylem zarządzania. W stylu nieinteraktywnym członkowie społeczności lokalnej są jedynie informowani o zamierzeniach przedstawicieli władzy.

Zakres partycypacji może być także bardzo szeroki i polegać na realizowaniu przez partnerów społeczno-gospodarczych określonych zadań przy wsparciu organizacyjnym i finansowym jednostki samorządu terytorialnego. Zakres ten jest ściśle związany ze stylem interaktywnym zarządzania. W stylu interaktywnym wyróżnić możemy kilka poziomów partycypacji, począwszy od proponowania konkretnych rozwiązań wskazanego przez władze problemu, aż do inicjowania i realizacji działań (Gawroński, 2007, s. 144-148).

W latach 60. XX w. w Stanach Zjednoczonych Sherr R. Arnstein opracowała słynną „drabinę partycypacji”. Jej stworzenie wynikało z obserwowanego w tym czasie ograniczenia udziału ubogich grup społecznych w programach pomocy. Z założenia mieli to być główni odbiorcy tych programów w ramach „,community action programs". Idea drabiny partycypacji polegała na zestawieniu ze sobą bezsilnych grup mieszkańców z tymi, którzy mają władzę i wpływ na podejmowane decyzje. W wyniku tego podkreślono fundamentalne różnice między omawianymi dwiema grupami. Wyróżniono różne poziomy partycypacji głównie na poziomie samorządów lokalnych, które związane były z funkcjonowaniem służb publicznych. Jest to osiem poziomów partycypacji: manipulacja, terapia, informowanie, konsultacje, łagodzenie, partnerstwo, delegowanie i kontrola obywatelska. Dwa pierwsze i zarazem najniższe poziomy (manipulacja i terapia) w drabinie określane są jako niepartycypacyjne. Kolejne trzy (informowanie, konsultowanie i łagodzenie - umieszczanie w grupach doradczych) uznawane są za partycypację pozorowaną. Według autorki partycypacja rozpoczyna się od partnerstwa. Najważniejsze dwa poziomy zaawansowanego udziału społeczności lokalnej w życiu wspólnoty to delegowanie władzy i kontrola obywateli (sprawowana nad instytucjami) (Olech, 2011, s. 85-100).

Drabina partycypacji opracowana przez S. R. Arnstein została przez lata zmodyfikowana i dostosowana do współczesnej europejskiej rzeczywistości. Uproszczony schemat zakresu i odpowiadających mu form partycypacji w zależności od realizowanego stylu zarządzania w jednostkach samorządu terytorialnego prezentuje „drabina partycypacji” (tab. 1). 


\begin{tabular}{|c|c|c|c|c|}
\hline$\frac{\frac{a}{0}}{\frac{\pi}{\sqrt{n}}}$ & 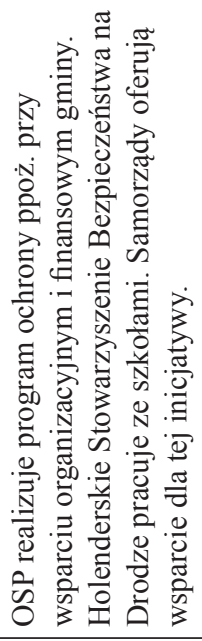 & 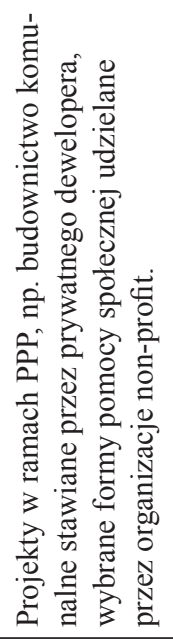 & 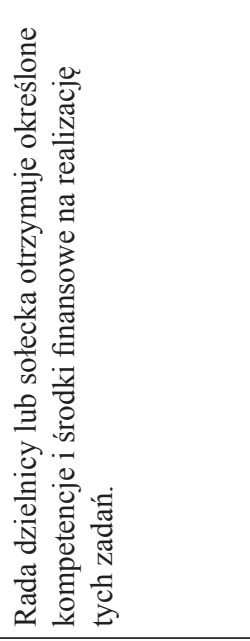 & 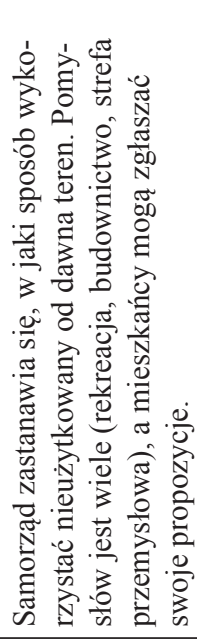 \\
\hline 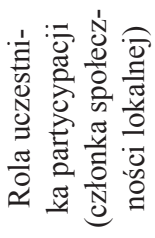 & 离 & 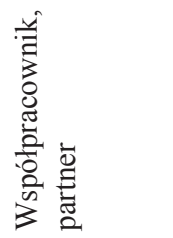 & 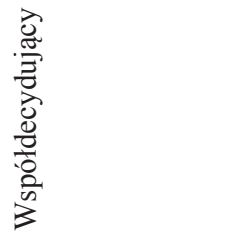 & 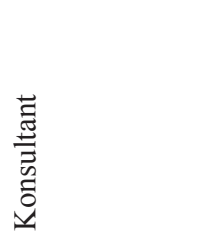 \\
\hline 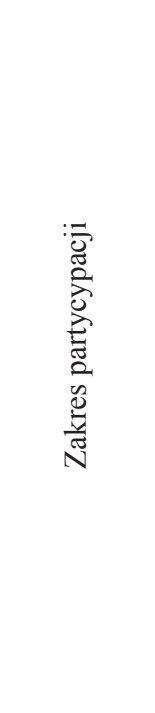 & 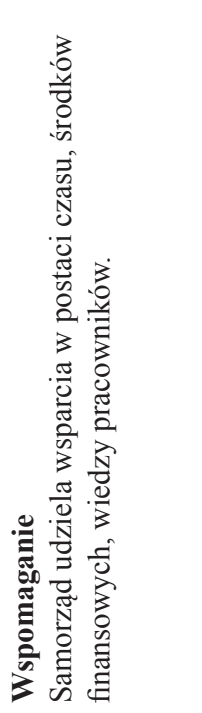 & 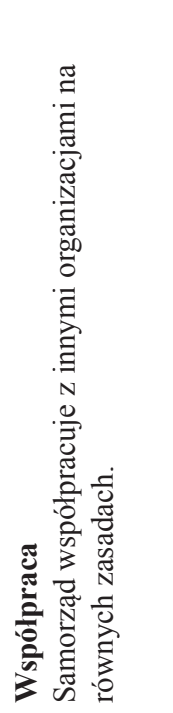 & 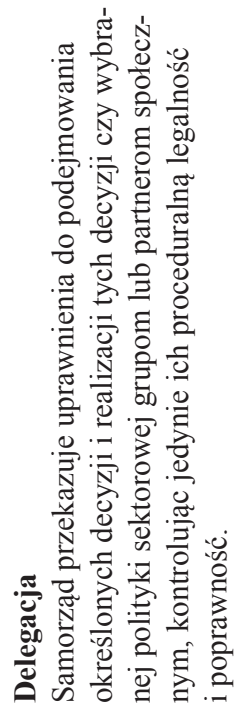 & 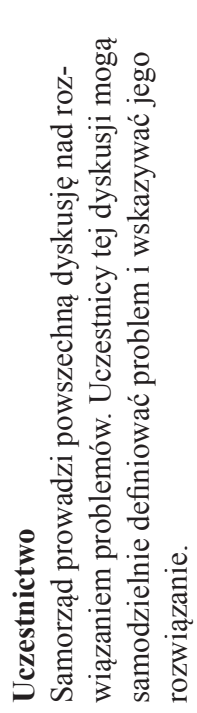 \\
\hline 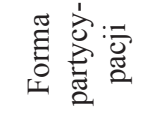 & \multicolumn{4}{|l|}{ 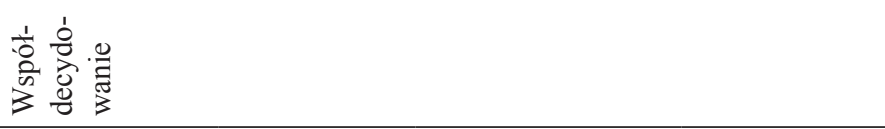 } \\
\hline 离莺 & \multicolumn{4}{|l|}{ 吾莺怘 } \\
\hline
\end{tabular}




\begin{tabular}{|c|c|c|}
\hline 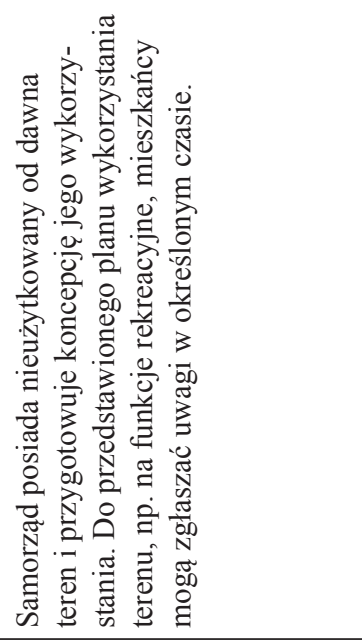 & 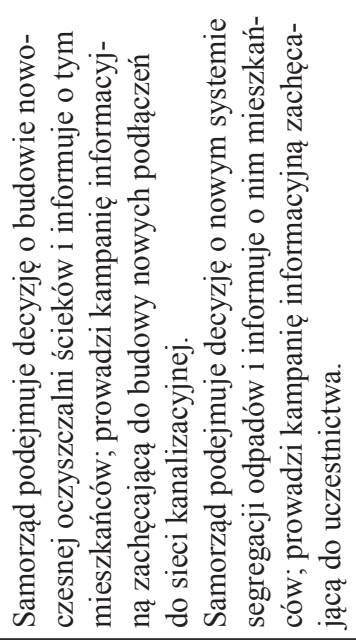 & 1 \\
\hline 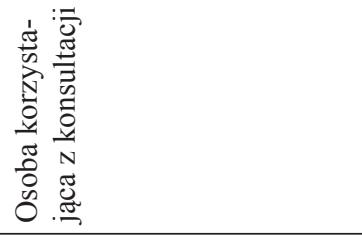 & 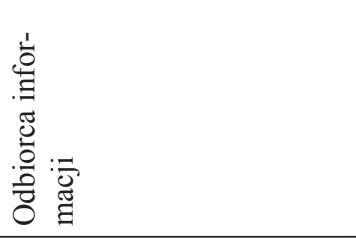 & 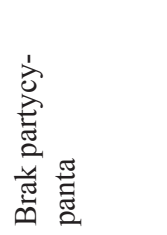 \\
\hline 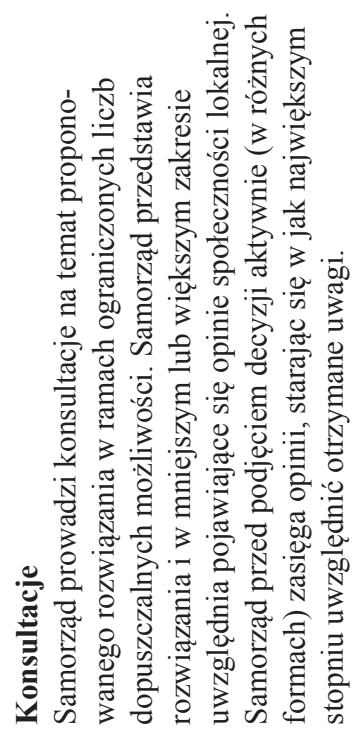 & 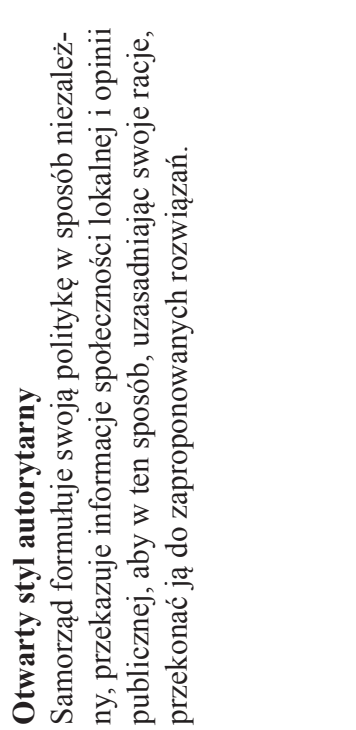 & 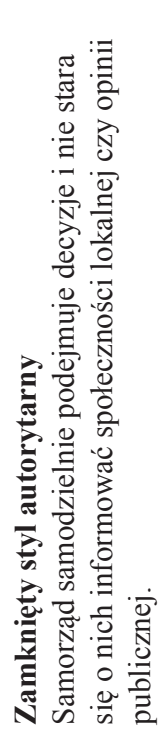 \\
\hline 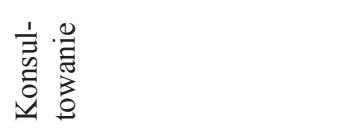 & 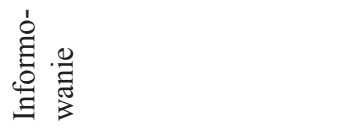 & 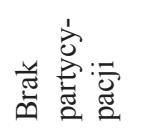 \\
\hline \multicolumn{3}{|l|}{ 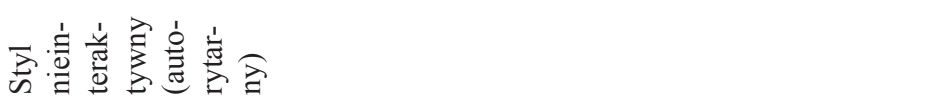 } \\
\hline
\end{tabular}


W literaturze przedmiotu opisującej procesy partycypacyjne wskazuje się dwa sposoby podejmowania decyzji w samorządzie terytorialnym. Pierwszym z nich jest typ agregujący (ang. aggregative), oparty na woli większości. Odwołuje się on do klasycznej zasady demokracji stanowiącej, gdzie mieszkańcy danej społeczności mają moralne zobowiązania do poszanowania i przestrzegania decyzji większości, nawet w sytuacji, gdy decyzje te są sprzeczne z ich partykularnymi interesami. Drugi to typ deliberujący (ang. deliberative), w którym poszukuje się konsensusu poprzez szeroką debatę publiczną. Odnosi się on do przekonania, że szeroka debata publiczna prowadzi do konsensusu i inkluzji znacznej części podmiotów społeczno-gospodarczych. W tej sytuacji władze samorządowe mają obowiązek stworzenia warunków do takiej debaty. Różnice w typach procesów decyzyjnych agregującym i deliberującym przedstawia tab. 2 .

Tabela 2. Partycypacja społeczna według typu procesu decyzyjnego

\begin{tabular}{|l|l|l|}
\hline \multirow{2}{*}{$\begin{array}{c}\text { Fazy procesu budowania polityki } \\
\text { publicznej }\end{array}$} & \multicolumn{2}{|c|}{ Typ procesu decyzyjnego } \\
\cline { 2 - 3 } Opracowywanie polityki & $\begin{array}{l}\text { agregujący } \\
\text { lobbing, petycje, stanowiska, } \\
\text { demonstracje }\end{array}$ & $\begin{array}{l}\text { deliberujący } \\
\text { nizowanych przez władze } \\
\text { lokalne }\end{array}$ \\
\hline Podejmowanie decyzji & referenda lokalne & $\begin{array}{l}\text { decyzje podejmowane } \\
\text { w koalicjach poziomych } \\
\text { skupiających publicznych } \\
\text { i prywatnych partnerów }\end{array}$ \\
\hline Realizacja & & $\begin{array}{l}\text { udział organizacji pozarządo- } \\
\text { wych w realizacji polityki }\end{array}$ \\
\hline
\end{tabular}

Źródło: Klassen, Sweeting, 2004, za: Swianiewicz, 2008, s. 39, 78.

\subsection{Modele partycypacji społecznej}

Jednostki samorządu terytorialnego w Polsce różnią się pod względem udziału mieszkańców w podejmowaniu wspólnie z władzami decyzji o charakterze publicznym. Różnice te związane są ze specyfiką zarządzania, a także formami, jakie stosowane są w procesie angażowania społeczności lokalnej w sprawy lokalne. W literaturze przedmiotu wskazuje się modele partycypacji charakterystyczne dla poszczególnych typów jednostek w zależności od ich stopnia otwartości na udział mieszkańców, stopnia zaangażowania we współdecydowaniu o kształcie polityki lokalnej. 
Istnieją cztery modele partycypacji:
a) asymetryczny,
b) opiniodawczo-konsultacyjny,
c) symetryczny,
d) delegacyjny.

Asymetryczny model partycypacji charakteryzuje się asymetryczną relacją między władzą lokalną a społecznością lokalną, która zakłada pierwszeństwo dla pozycji władzy samorządowej. Ma ona w tym modelu dominującą rolę na każdym etapie formułowania i realizowania polityk publicznych. W modelu tym władze samorządowe całkowicie samodzielnie podejmują decyzje. Są to działania inicjowane i realizowane w sposób jednostronny i całkowicie autorytarny. Polityka władz samorządowych w tym przypadku może być realizowana w dwojaki sposób:

- po pierwsze, władze samorządowe działają samodzielnie, ale po podjęciu decyzji czy realizacji działań informują o nich społeczność lokalną;

- po drugie, władze samorządowe działają całkowicie jednostronnie i samodzielnie, ale poza informowaniem o swoich decyzjach i działaniach uzasadniają je, próbując nakłonić mieszkańców do ich akceptacji.

Istotą relacji władze-mieszkańcy w tym modelu jest jednokierunkowy przepływ komunikatów od jednostki samorządu terytorialnego do społeczności lokalnej. Nie istnieje przepływ informacji w drugą stronę, bo władze nie są tym zainteresowane. Oficjalne, wykorzystywane kanały komunikacji służą jedynie informowaniu społeczności lokalnej i są zamknięte na przepływ informacji w odwrotną stronę. W tej jednokierunkowej komunikacji między jednostką samorządu terytorialnego a mieszkańcami przyjmuje się różne style w zależności od zidentyfikowanych odbiorców oraz wykorzystuje różne środki komunikacji.

Badania dotyczące rozkładu modeli partycypacji społecznej w Polsce na podstawie indeksu partycypatywności jednostek samorządu terytorialnego wskazują szereg form informowania i wyjaśniania wykorzystywanych w modelu asymetrycznym (tab. 3).

Wyniki badań wskazują, że model asymetryczny stosowany jest w jednej piątej $(20,1 \%)$ gmin w Polsce. Wskazują one również, że w 12,4\% gmin stosowano pierwszy wariant, związany z informowaniem o podejmowanych decyzjach. Ponadto $\mathrm{w} 7,7 \%$ gmin decyzję tę próbowano uzasadniać, aby przekonać mieszkańców do jej akceptacji. Wyniki badań wskazują, że aż w jednej piątej gmin w Polsce władze samorządowe podejmują decyzje i realizują działania samodzielnie i bez udziału społeczności lokalnej²

2 Badanie „Rozkład modeli partycypacji publicznej w Polsce - indeks partycypatywności”. W badaniu próbowano odpowiedzieć m.in. na pytanie o to, jaki odsetek gmin w Polsce stosuje poszczególne modele partycypacji publicznej. Wyniki badań prezentują maksymalne zidentyfikowane modele, czyli ich górną granicę i maksymalnie osiągnięty poziom na drabinie partycypacji. Źródło: Badanie stanu partycypacji publicznej, Instytut Spraw Publicznych, projekt „Decydujmy razem”, 2011/2012 rok. 
Tabela 3. Ocena form informowania społeczności lokalnej w jednostkach samorządu terytorialnego w Polsce

\begin{tabular}{|c|c|c|c|}
\hline \multirow{7}{*}{$\begin{array}{l}\text { Formy } \\
\text { informo- } \\
\text { wania } \\
\text { i wyja- } \\
\text { śniania } \\
\text { w modelu } \\
\text { asyme- } \\
\text { trycznym }\end{array}$} & Oceniane najlepiej & Oceniane przeciętnie & Oceniane najsłabiej \\
\hline & \multirow[t]{2}{*}{$\begin{array}{l}\text { Przekazywanie informa- } \\
\text { cji i wyjaśnień bezpo- } \\
\text { średnio podczas spotkań } \\
\text { i zebrań z mieszkańcami }\end{array}$} & $\begin{array}{l}\text { Przekazywanie informacji } \\
\text { i uzasadnień jednostkom } \\
\text { pomocniczym do dalszego } \\
\text { upowszechniania }\end{array}$ & $\begin{array}{l}\text { Zamieszczanie informacji } \\
\text { na tablicy ogłoszeń przed } \\
\text { urzędem gminy }\end{array}$ \\
\hline & & $\begin{array}{l}\text { Rozsyłanie informacji } \\
\text { i uzasadnień do zaintere- } \\
\text { sowanych osób, organiza- } \\
\text { cji, instytucji }\end{array}$ & $\begin{array}{l}\text { Zamieszczanie informacji na } \\
\text { tablicach ogłoszeń w po- } \\
\text { szczególnych miejscowo- } \\
\text { ściach lub dzielnicach }\end{array}$ \\
\hline & \multirow{2}{*}{$\begin{array}{l}\text { Przekazywanie informa- } \\
\text { cji i wyjaśnień bezpo- } \\
\text { średnio podczas spotkań } \\
\text { i zebrań z przedstawicie- } \\
\text { lami jednostek pomocni- } \\
\text { czych (m.in. sołtysami, } \\
\text { przedstawicielami rad } \\
\text { dzielnicowych) }\end{array}$} & $\begin{array}{l}\text { Występowanie w lokal- } \\
\text { nych programach radio- } \\
\text { wych, telewizyjnych }\end{array}$ & $\begin{array}{l}\text { Zamieszczanie informacji } \\
\text { w biuletynie informacji } \\
\text { publicznej }\end{array}$ \\
\hline & & $\begin{array}{l}\text { Przekazywanie informacji } \\
\text { i uzasadnień do lokalnych } \\
\text { mediów }\end{array}$ & $\begin{array}{l}\text { Zamieszczanie informacji na } \\
\text { stronie internetowej urzędu }\end{array}$ \\
\hline & \multirow[t]{2}{*}{$\begin{array}{l}\text { Przekazywanie informa- } \\
\text { cji i wyjaśnień bezpo- } \\
\text { średnio podczas spotkań } \\
\text { i zebrań z organizacjami } \\
\text { pozarządowymi }\end{array}$} & $\begin{array}{l}\text { Publikowanie ogłoszeń } \\
\text { lub artykułów na stronach } \\
\text { wykupywanych w prasie } \\
\text { lokalnej }\end{array}$ & $\begin{array}{l}\text { Zamieszczanie informacji } \\
\text { w drukowanym biuletynie, } \\
\text { wydawanym przez urząd } \\
\text { gminy }\end{array}$ \\
\hline & & $\begin{array}{l}\text { Przekazywanie informacji } \\
\text { i uzasadnień w trakcie } \\
\text { konferencji prasowych }\end{array}$ & $\begin{array}{l}\text { Upowszechnianie informa- } \\
\text { cji nieformalnym obiegiem } \\
\text { „Z ust do ust” }\end{array}$ \\
\hline
\end{tabular}

Źródło: Badanie stanu partycypacji publicznej, Instytut Spraw Publicznych, projekt „Decydujmy razem", 2011/2012.

Opiniodawczo-konsultacyjny model partycypacji charakteryzuje się natomiast asymetrią w relacji między władzą lokalną a społecznością lokalną. W modelu tym decyzje i planowane działania władz samorządowych są konfrontowane z opinią publiczną, a społeczność lokalna może przedstawiane decyzje i działania modyfikować. Tu, podobnie jak w modelu asymetrycznym, podstawą jest informowanie społeczności lokalnej o decyzjach i planach, ale przepływ informacji następuje również $\mathrm{w}$ drugą stronę. Władze samorządowe w modelu opiniodawczo-konsultacyjnym przyjmują jednak dwie postawy, otrzymując informacje od społeczności lokalnej. Po pierwsze, dopuszczają i przyjmują do wiadomości stanowiska przedstawiane przez mieszkańców i w mniejszym lub większym stopniu wykorzystują je do modyfikacji swoich planów. Bardziej otwarta z kolei jest 
druga postawa władz samorządowych, która zakłada intencjonalność zbierania opinii i uwag od mieszkańców. Polega ona na aktywnym zasięganiu opinii, czyli na prowadzeniu formalnie zorganizowanych konsultacji społecznych, których wyniki w mniejszym lub większym zakresie uwzględniane są w formułowaniu ostatecznych rozwiązań i decyzji. Badania dotyczące rozkładu modeli partycypacji społecznej w Polsce na podstawie indeksu partycypatywności jednostek samorządu terytorialnego wskazują szereg form konsultacji wykorzystywanych w tym modelu ${ }^{3}$.

Wyniki badań jednoznacznie wskazują, że model opiniodawczo-konsultacyjny dominuje w polskich samorządach. W co drugiej gminie władze samorządowe co najmniej raz w roku prowadzą konsultacje społeczne. Jednocześnie w samorządach tych mieszkańcy nie byli angażowani szerzej w proces podejmowania decyzji.

Symetryczny model partycypacji charakteryzuje się zrównoważoną relacją między władzą samorządową a społecznością lokalną. W modelu tym zakłada się partnerskie relacje między uczestnikami procesu partycypacji. Żadna ze stron nie posiada dominującej roli na którymkolwiek etapie budowania polityk publicznych. Władze samorządowe, przystępując do podejmowania decyzji i planowania działań, zapraszają partnerów społeczno-ekonomicznych i w tym procesie razem z nimi współtworzą plany i podejmują decyzje. Ten typ partnerskiej relacji między uczestnikami najlepiej oddaje ducha demokracji deliberacyjnej, która polega na wspólnym poszukiwaniu i znajdowaniu rozwiązań istotnych problemów danej wspólnoty. W modelu tym mogą być również wykorzystywane inne tradycyjne formy negocjacji, gdzie podczas dyskusji nad danymi problemami z wypracowanymi wcześniej stanowiskami różnych stron podejmowane są wspólne decyzje i budowane plany.

Badania dotyczące rozkładu modeli partycypacji społecznej w Polsce na podstawie indeksu partycypatywności jednostek samorządu terytorialnego wskazują wykorzystywane w tym modelu formy wspólnego przygotowania projektów decyzji i uchwał. Pierwszą z nich jest formalnie powołany zespół, który składa się z przedstawicieli społeczności lokalnej (mieszkańcy, organizacje pozarządowe i związki zawodowe) oraz przedstawicieli władz jednostki samorządu terytorialnego. Drugą formą jest działanie nieformalnej grupy roboczej złożonej, podobnie jak w poprzednim wariancie, z przedstawicieli społeczności lokalnej oraz przed-

3 Wykorzystywane w tym modelu formy konsultacji w polskich samorządach to m.in. debaty prowadzone przez niezależnego moderatora, których efektem były wspólne ustalenia; wysłuchanie publiczne; stałe komisje lub sesje plenarne rad gmin, na które zapraszani byli przedstawiciele organizacji pozarządowych i mieszkańców; spotkania lub zebrania z mieszkańcami; spotkania lub zebrania z organizacjami pozarządowymi i przedstawicielami jednostek pomocniczych; badania ankietowe; specjalny punkt konsultacyjny; stałe rady opiniodawczo-konsultacyjne; zbieranie opinii za pośrednictwem przedstawicieli jednostek pomocniczych; zbieranie opinii za pośrednictwem radnych gminnych; zbieranie podpisów deklarujących poparcie lub brak poparcia dla proponowanych rozwiązań; zbieranie pisemnych opinii; zbieranie opinii mieszkańców za pośrednictwem Internetu (Badanie stanu partycypacji publicznej, 2011/2012). 
stawicieli władz jednostki samorządu terytorialnego. Trzecią wykorzystywaną formą w tym modelu jest działanie grupy składającej się z członków stałego zespołu konsultacyjnego i przedstawicieli władzy.

Delegacyjny model partycypacji charakteryzuje się asymetrią relacji między władzą samorządową a społecznością lokalną, jednak tutaj kierunek tej asymetrii jest przeciwny do tego, który występuje w modelu asymetrycznym. W modelu tym zakłada się całkowite oddanie członkom społeczności lokalnej sprawstwa nad decyzjami i działaniami. Władza samorządowa wycofuje się z aktywnego uczestnictwa w podejmowaniu decyzji, delegując podmiotom $\mathrm{z}$ sektora społeczno-ekonomicznego decyzyjność z obietnicą „zrobimy to, co zdecydujecie”, a nawet delegując wykonanie tych decyzji z obietnicą ,zdecydujcie i zrealizujcie to". Władze samorządowe przekazują więc podejmowanie decyzji i ich realizację społeczności lokalnej, pozostawiając sobie jedynie kontrolę nad poprawnością i zgodnością realizowanych działań z obowiązującym prawem.

Badania dotyczące rozkładu modeli partycypacji społecznej w Polsce na podstawie indeksu partycypatywności jednostek samorządu terytorialnego wskazują, że model ten stosowany jest zaledwie w $12,9 \%$ polskich gmin. Wśród podmiotów, na które władze samorządowe delegują decyzje i działania, wymienia się w kolejności grupy mieszkańców, przedstawicieli organizacji pozarządowych oraz ekspertów wskazanych przez mieszkańców, przedstawicieli jednostek pomocniczych oraz członków stałego zespołu konsultacyjnego, który funkcjonuje w jednostce samorządu terytorialnego (Olech, 2013, s. 25-52).

\subsection{Instytucjonalno-prawne uwarunkowania udziału mieszkańców w procesach decyzyjnych}

Jedną z podstawowych kwestii, które pojawiają się w praktyce inicjowania i prowadzenia procesu partycypacji społecznej w Polsce są uregulowania prawne i instytucjonalne. Wynikają one z międzynarodowych, krajowych, a także lokalnych uwarunkowań. Współcześnie $\mathrm{w}$ krajach europejskich podkreślana jest potrzeba uzgadniania decyzji administracyjnych ze wspólnotami samorządowymi i narodowymi. Jednak $\mathrm{z}$ uwagi na duże różnice $\mathrm{w}$ regulacjach prawnych na szczeblu krajowym, dotyczące poziomu sformalizowania, zakresu oraz trybu prowadzenia m.in. konsultacji społecznych potrzebne okazało się opracowanie ramowych założeń na szczeblu wspólnoty europejskiej. Podmioty odpowiedzialne za te działania funkcjonują głównie w sektorze publicznym i społecznym, stąd też dość konkretne reguły ich postępowania.

Jednym z podstawowych aktów prawnych regulujących udział społeczności lokalnej w życiu publicznym jest Europejska Karta Samorządu Lokalnego (Dz. U. 1994, nr 124, poz. 607) uchwalona przez Stałą Konferencję Gmin i Regionów Rady Europy w październiku 1985 r. Konwencja, którą Polska ratyfikowała 
w kwietniu 1993 r., mocno podkreśla ducha demokracji i obywatelskości jako prawo obywateli i jedną z podstawowych wartości wspólnoty europejskiej. Były w niej zawarte postanowienia nakładające obowiązek konsultowania ze społecznościami lokalnymi wszelkich spraw związanych z:

a) decyzjami i opracowaniem planów dotyczących bezpośrednio tych wspólnot (art. 4, ust. 6);

b) zmianą granic obszaru zamieszkiwanego przez te społeczności (art. 5);

c) formami przyznawania zasobów pochodzących z redystrybucji dochodów (art. 9, ust. 6) (Zychowicz, 2011, s. 17).

Władze samorządowe są instytucją odpowiedzialną za partycypacyjne zarządzanie i koordynację polityk publicznych. Jednak w myśl zasady subsydiarności ma się to odbywać we współpracy ze społecznością lokalną.

Europejska Karta Samorządu Lokalnego (Dz. U. 1994, nr 124, poz. 607) zawiera postulaty i ma charakter ramowy, który szczegółowe rozwiązania pozostawia poszczególnym krajom. W Polsce postulaty tej karty znalazły swoje odzwierciedlenie w zapisach Konstytucji Rzeczypospolitej Polskiej (Dz. U. 1997, $\mathrm{nr} 78$, poz. 483) oraz ustawodawstwie zwykłym. Ponadto istnieje szereg opracowanych na poziomie międzynarodowym dokumentów, które nie zostały przez Polskę ratyfikowane. Są to m.in. Europejska Karta Samorządu Regionalnego z 1997 r. uchwalona przez Kongres Władz Lokalnych i Regionalnych Europy; Karta Uczestnictwa Młodych w Życiu Lokalnym i Regionalnym z 1992 r. (Zychowicz, 2011, s. 17).

$\mathrm{Z}$ uwagi na taką sytuację widoczne jest duże zróżnicowanie uwarunkowań prawnych społeczności lokalnych i regionalnych, które mogą bezpośrednio uczestniczyć w konsultacjach w poszczególnych krajach. Unia Europejska stosuje wiele zróżnicowanych procedur konsultacyjnych. To zróżnicowanie na poziomie poszczególnych Państw członkowskich Unii Europejskiej nie znajduje jednak odzwierciedlenia w aktach prawa unijnego. Największe znaczenie dla instytucji publicznych w Unii Europejskiej mają postanowienia Komisji Europejskiej (KE) z 11 grudnia 2002 r. Komunikat Komisji Europejskiej „Główne zasady i minimalne standardy konsultacji zainteresowanych stron przez Komisję Europejską” (COM/2002/0704) określa podstawowe zasady konsultowania ze społecznością lokalną. Są to: aktywne uczestnictwo, otwartość i odpowiedzialność, efektywność oraz spójność. Zidentyfikowanym celem zaproponowanych przez Komisję Europejską rozwiązań jest pogłębienie otwartości i dostępu do instytucji unijnych. W komunikacie sformułowano minimalne standardy prowadzenia konsultacji ze społecznościami terytorialnymi. Zaliczono do nich:

a) powszechny dostęp do informacji dotyczących procesu konsultacji dla wszystkich uczestników;

b) powszechny dostęp do procesu konsultacji dla wszystkich zainteresowanych; 
c) uwzględnienie w procesie konsultacji stanowisk wszystkich zainteresowanych podmiotów;

d) wyznaczenie limitów czasowych na przeprowadzenie poszczególnych elementów procesu konsultacji, czyli odpowiedni czas na zgłaszanie uwag i opinii, i 20 dni na zaproszenie na otwarte publiczne spotkanie;

e) upublicznienie wyników konsultacji.

Standardy te zostały opracowane dla inicjatyw Komisji Europejskiej i stały się przykładami dla rozwiązań szczegółowych w krajach wspólnoty i ich urzędów. Podmiotami odpowiedzialnymi za wdrażanie mechanizmów konsultacyjnych uważane są przede wszystkim Komitet Regionów oraz Komitet Ekonomiczno-Społeczny.

Ponadto Konwencja o Dostępie do Informacji, Udziale Społeczeństwa w Podejmowaniu Decyzji oraz Dostępie do Sprawiedliwości w Sprawach Środowiska $^{4}$ (tzw. Konwencja z Aarhus, Dz. U. 2003, nr 78, poz. 706) wprowadza zasady udziału społeczności lokalnej m.in. w decyzjach dotyczących ochrony środowiska. Uchwalona przez Europejską Komisję Gospodarczą ONZ w 1998 r. i przez Radę Unii Europejskiej w 2005 r. konwencja wprowadza normy w zakresie przejrzystości decyzji administracyjnych, gwarantując wspólnotom lokalnym, regionalnym i ponadregionalnym prawo do informacji oraz czynnego udziału w procesie podejmowania decyzji. Władze publiczne są zatem zobowiązane przepisami tej konwencji do włączania społeczności lokalnej w proces podejmowania decyzji dotyczących określonych przedsięwzięć i zezwoleń o dużym znaczeniu dla środowiska (art. 6). Ponadto w konwencji wskazany jest udział członków wspólnoty w procesie kształtowania planów, programów i wytycznych polityki o istotnym znaczeniu dla ochrony środowiska (art. 7), w tym także wskazuje się regulacje dla niektórych form tego udziału. Dodatkowo podkreśla ona konieczność uczestnictwa w tworzeniu norm prawnych dotyczących ochrony środowiska (art. 8) oraz wskazuje sposoby udziału społeczności lokalnych w tych procedurach (Konwencja o Dostępie do Informacji, Udziale Społeczeństwa w Podejmowaniu Decyzji oraz Dostępie do Sprawiedliwości w Sprawach Środowiska, Dz. U. 2003, nr 78, poz. 706).

Konwencja z Aarhus zainicjowała powstanie kolejnych dokumentów regulujących kwestie procesu partycypacji społecznej. Ogólne zasady zostały uszczegółowione oraz rozszerzone na inne sfery życia publicznego m.in. przez:

a) zapisy Dyrektywy 2003/35/WE, która wprowadza obowiązek udziału społeczności lokalnej w procesie budowania planów i programów przewidzianych w innych przepisach. Dyrektywa została opracowana w celu zapewnienia zgodności z rozwiązaniami zaproponowanymi w konwencji z Aarhus (Dyrektywa 2003/35/WE Parlamentu Europejskiego);

\footnotetext{
${ }_{4}$ Polska ratyfikowała konwencję w 2002 r.
} 
b) zapisy Białej Księgi „European Governance” z lipca 2001 r., (White Paper: European Governance, 2001);

c) zapisy Dyrektywy Rady UE 85/337/EWG i 96/61/WE z 2003 r., (Dyrektywa Rady 85/337/EWG; Dyrektywa Rady 96/61/WE);

d) zapisy Rozporządzenia (WE) 1367/2006 z 2006 r. w sprawie zastosowania postanowień Konwencji z Aarhus [...] (Zychowicz, 2011, s. 17; Jak prowadzić konsultacje spoleczne w samorzadach, 2010, s. 18-22).

Polskie prawodawstwo dostosowywane jest do rozwiązań postulowanych przez Unię Europejską. Stopniowo wprowadzane są rozwiązania dotyczące partycypacji społecznej, ale wciąż istnieją znaczące deficyty, związane z niedookreśleniem m.in. podstawowych pojęć związanych z partycypacją czy też konsultacjami społecznymi realizowanymi przez jednostki samorządu terytorialnego. Ta sytuacja powoduje, że samorządy same interpretują te pojęcia i realizują wielokrotnie działania, które tylko z nazwy odpowiadają np. konsultacjom. Wytyczne dotyczące prowadzenia procesu partycypacji zawarte są w różnych przepisach polskiego prawa (m.in. w konstytucji, w ustawach, rozporządzeniach itp.).

Podstawą prawną do realizacji przez jednostki samorządu terytorialnego w Polsce działań związanych z udziałem społeczności lokalnych w procesach decyzyjnych są następujące przepisy prawa:

a) Konstytucja Rzeczypospolitej Polskiej z 1997 r., która wskazuje zasady związane $\mathrm{z}$ budowaniem społeczeństwa obywatelskiego, tj. zasadę demokratycznego państwa prawa, zasadę dialogu społecznego, zasadę społecznej gospodarki rynkowej, zasadę pomocniczości oraz zasadę suwerenności narodu, samorządności, społeczeństwa obywatelskiego oraz zasady praw i wolności obywatelskich, prawo obywatela do uzyskania i rozpowszechniania informacji (Konstytucja Rzeczypospolitej Polskiej, Dz. U. 1997, nr 78, poz. 483);

b) ustawy o samorządzie gminnym z 1990 r. (Ustawa o samorządzie gminnym, Dz. U. 1990, nr 16, poz. 95), powiatowym i województwa z 1998 r. (Ustawa o samorządzie powiatowym, Dz. U. 1998, nr 91, poz. 578; Ustawa o samorządzie województwa, Dz. U. 1998, nr 91, poz. 576) wskazujące konsultacje obligatoryjne i fakultatywne, które może realizować samorząd w oparciu o wypracowane zasady i procedury;

c) ustawa o działalności pożytku publicznego i wolontariacie z 2003 r. (Ustawa o działalności pożytku publicznego i o wolontariacie, Dz. U. 2003, nr 96, poz. 873), która mówi o obowiązku konsultowania projektów aktów normatywnych w dziedzinach dotyczących działalności statutowej tychże organizacji. Nowelizacja tej ustawy wydaje się, że rozpoczęła nowy okres we współpracy jednostek samorządu terytorialnego, administracji publicznej ze społecznością lokalną, organizacjami społecznymi czy też samymi mieszkańcami. Nowelizacja wprowadziła bowiem wcześniej wymieniony obowiązek konsultowania nie tylko programów współpracy z organizacjami pozarządowymi. Ustawa wskazuje, że również inne 
dokumenty, opracowywane przez samorządy, posiadające charakter prawa miejscowego lub normatywnego muszą być poddane konsultacjom;

d) ustawa o udostępnieniu informacji o środowisku i jego ochronie, udziale społeczeństwa $\mathrm{w}$ ochronie środowiska oraz o ocenach oddziaływania na środowisko z 2008 r. (Dz. U. 2008, nr 199, poz. 1227), która określa udział społeczności lokalnej w procesie ochrony środowiska naturalnego i przyrodniczego oraz udział w opiniowaniu ocen oddziaływania na środowisko;

e) ustawa o Trójstronnej Komisji do Spraw Społeczno-Gospodarczych i wojewódzkich komisjach dialogu społecznego z 2001 r. (Dz. U. 2001, nr 100, poz. 1080);

f) ustawa o planowaniu i zagospodarowaniu przestrzennym z 2003 r. (Dz. U. 2003, nr 80, poz. 717), która buduje system opiniowania, konsultowania i debatowania nad polityką przestrzenną w jednostkach samorządu terytorialnego;

g) ustawa o zasadach prowadzenia polityki rozwoju z 2006 r. (Dz. U. 2006, nr 227, poz. 1658);

h) ustawa o promocji zatrudnienia i instytucjach rynku pracy z 2004 r. (Dz. U. 2004, nr 99, poz. 1001);

i) ustawa o pomocy społecznej z 2004 r. (Dz. U. 2004, nr 64, poz. 593).

Poza wskazanymi regulacjami na poziomie krajowym w zakresie partycypacji społecznej samorządy w Polsce posiadają możliwość samostanowienia zasad, reguł i form wykorzystywanych $\mathrm{w}$ tym procesie, stąd też wynikają bardzo duże różnice w sposobie prowadzenia tego procesu i w zaangażowaniu społeczności lokalnej. Do głównych dokumentów, które stanowią o zakresie partycypacji społecznej należą m.in.: uchwały i zarządzenia organów stanowiących i wykonawczych prawo lokalne, procedury dotyczące współpracy z organizacjami pozarządowymi, regulacje oraz inne akty prawa lokalnego:

a) W statucie jednostki samorządu terytorialnego znajdują się wzmianki i regulacje dotyczące funkcjonowania jednostek pomocniczych samorządu, co stanowi jeden z przejawów udziału mieszkańców w życiu wspólnoty;

b) Uchwała rady gminy, powiatu, województwa jest najczęściej występującym aktem prawa w tym zakresie. Rada jednostki samorządu terytorialnego uchwałą reguluje zasady, procedury, formy prowadzenia m.in. konsultacji społecznych z mieszkańcami lub organizacjami pozarządowymi. Jednostki samorządu terytorialnego wprowadzają także regulaminy konsultacji społecznych;

c) Uchwała rady gminy, powiatu, województwa w sprawie konsultacji społecznych z udziałem organizacji pozarządowych i podmiotów, o których wspomina ustawa o działalności pożytku publicznego i wolontariacie wprowadza regulacje w kwestii prowadzenia konsultacji społecznych. Uchwała ta przyjmuje postać programu współpracy z organizacjami pozarządowymi, który reguluje także zasady zlecania zadań publicznych do realizacji tym organizacjom;

d) Zarządzenia organów wykonawczych regulują szczegółowe kwestie związane z udziałem mieszkańców w życiu wspólnoty terytorialnej. Odnoszą się 
one do różnych elementów procesu konsultacji czy też powołania ciał opiniodawczych i konsultacyjnych (np. rady działalności pożytku publicznego) (Zychowicz, 2011, s. 17; Jak prowadzić konsultacje społeczne w samorządach, 2010, s. 18-22).

Polskie prawodawstwo i prawo lokalne stanowione przez samorządy tworzy formalne otoczenie, w jakim prowadzony jest proces partycypacji społecznej. Polskie regulacje prawne dostosowywane są do standardów międzynarodowych w tworzeniu klimatu i warunków do rozwoju społeczeństwa obywatelskiego. Mimo wielu formalnych deficytów i rozwiązań definicyjnych wydaje się, że nie stanowi to bariery w tworzeniu nowych rozwiązań w samorządach. Duża dowolność w decydowaniu o sposobie, zasadach i trybie uczestnictwa mieszkańców w stanowieniu prawa lokalnego i polityk publicznych niestety nie przekłada się na rzeczywistość, gdyż samorządy w Polsce nie mają jeszcze świadomości korzyści płynących ze współpracy ze społecznością lokalną.

\subsection{Bariery procesu partycypacji społecznej}

Pomimo bardzo korzystnego wpływu partycypacji społecznej na zarządzanie i rozwój jednostek samorządu terytorialnego istnieje nadal wiele problemów, które wymagają pilnego rozwiązania, aby administracja publiczna i samorządowa w Polsce spełniała w pełni kryterium obywatelskości, otwartości i dobrego zarządzenia. Istnieje wiele barier partycypacji społecznej w Polsce, które znaleźć można po stronie zarówno samorządowej, jak i po stronie społeczności lokalnej.

Mieszkańcy nie uczestniczą w podejmowaniu publicznych decyzji z wielu powodów. Wśród nich można wymienić m.in. brak świadomości i kompetencji w zakresie funkcjonowania samorządu terytorialnego. Wiele procesów, procedur jest niezrozumiałych, a przez to sprawiają wrażenie skomplikowanych. Od dziesiątków lat panuje także przekonanie, że mieszkańcy w kontakcie z samorządem, urzędem publicznym niewiele mogą. Jest to spadek, jaki polskie społeczeństwo odziedziczyło po okresie realnego socjalizmu w Polsce.

Demokrację przedstawicielską traktuje się w samorządach jako najwłaściwszą formułę zarządzania jednostką samorządu terytorialnego. Dodatkowo wśród wielu polityków i przedstawicieli władzy samorządowej panuje przekonanie, że uzyskany mandat wyborczy daje im prawo do pełnego decydowania i lekceważącego stosunku wobec pojawiających się w debacie publicznej głosów mieszkańców, organizacji pozarządowych i politycznych reprezentujących różne interesy społeczne. Praktyką jest także zapraszanie do współpracy z przedstawicielami władzy samorządowej tylko takich organizacji, które wydają się być dla nich sojusznikami politycznymi lub mogą przyczynić się do wzrostu poparcia społecznego dla tych polityków. 
Ponadto polską administrację publiczną i samorządową cechuje wciąż niska kultura w zakresie współdziałania z partnerami społecznymi i prywatnymi. Stąd też proces partycypacji charakteryzuje się słabym przygotowaniem administracji do prowadzenia konsultacji społecznych, niską jakością, w tym także efektywnością, pomijaniem części partnerów tego procesu, nieprzestrzeganiem procedur prawnych regulujących konsultacje. O potrzebie partycypacji społecznej samorządy przypominają sobie z reguły w końcowym etapie kształtowania polityk publicznych, przekazując dokumenty do konsultacji „,na ostatni moment”, tuż przed ich zatwierdzeniem. Wiele jednostek samorządu terytorialnego świadomie element partycypacyjny pomija, gdyż nie wynika on w wielu przypadkach wprost z przepisów prawa. Nieuwzględnianie uwag zgłaszanych przez społeczność lokalną w procesie partycypacji społecznej potęguje tylko niechęć mieszkańców do angażowania się w sprawy wspólnoty terytorialnej. Nieuwzględnianie uwag przez administrację samorządową wynika $\mathrm{z}$ wielu przyczyn, m.in. z niechęci do pomysłów społeczności lokalnej, nieumiejętności wykorzystania wiedzy i informacji zebranych w toku konsultacji, zbyt późny moment, w którym przeprowadzone są działania partycypacyjne, co uniemożliwia korekty dokonanych zapisów w dokumentach.

Jednostki samorządu terytorialnego w wielu przypadkach bardzo formalnie traktują formy partycypacji, w tym również konsultacje społeczne. Traktowane są one proceduralnie, gdyż w świadomości przedstawicieli samorządu ich celem jest jedynie uniknięcie zarzutów proceduralnych i protestów społecznych związanych z brakiem konsultacji. Konieczność ich przeprowadzenia postrzegana jest przez pracowników administracji jako strata czasu i przede wszystkim konieczność wykonywania dodatkowych obowiązków w pracy. Wielu urzędnikom brakuje także kompetencji i umiejętności ich organizacji, a następnie realizacji, co powoduje, że niejednokrotnie konsultacje społeczne nie przynoszą zamierzonych efektów, co potęguje przeświadczenie o braku sensu ich organizowania.

Ze strony społeczności lokalnej partycypacja również spotyka się z różnymi barierami, wśród których wymienić można m.in. brak kompetentnych i sprawnych organizacyjnie partnerów społecznych do prowadzenia dialogu z administracją samorządową. Podmioty społeczne niejednokrotnie mylą konsultacje z negocjacjami czy też możliwością zawierania porozumień, co nasila niechęć do udziału w procesie partycypacji społecznej (Olech, 2013, s. 109-121).

Wymienione bariery i problemy związane z partycypacją społeczną w zarządzaniu jednostkami samorządu terytorialnego trudno będzie wyeliminować w najbliższych latach. To proces długotrwały, jednak w ostatnich latach nabiera większego tempa. Problemy te trudno będzie wyeliminować wyłącznie za pomocą instrumentów prawno-legislacyjnych. Wydaje się, że pozytywne zmiany, jakie zachodzą, są wynikiem praktyki i wzajemnego uczenia się współpracy przez wszystkie strony tego procesu. 


\section{Wybrane instrumenty partycypacyjne w teorii i praktyce}

\subsection{Konsultacje społeczne jako forma partycypacji społecznej}

Partycypacja społeczna jest procesem, w wyniku którego mieszkańcy i użytkownicy wspólnoty terytorialnej aktywnie uczestniczą w decydowaniu o sprawach dla nich ważnych. Zakres i intensywność procesu partycypacji społecznej są bardzo zróżnicowane. W zależności od zakładanego zakresu wyróżnia się różne formy partycypacji społecznej (informowanie, konsultowanie, współdecydowanie).

Konsultacje są jedną z form partycypacji społecznej, która zapewnia mieszkańcom udział $\mathrm{w}$ procesie decyzyjnym. Są one częścią procesu budowania wspólnoty lokalnej. Proces ten polega na poznawaniu potrzeb innych członków społeczności lokalnej, a następnie na wspólnym namyśle i znalezieniu konkretnych rozwiązań i działań. Konsultowanie ma charakter dwustronny - między administracją i mieszkańcami. Proces ten polega także na wspólnym przekonaniu, że celem tych działań jest dobro społeczności lokalnej. Jest to proces dialogu władz samorządowych z mieszkańcami mający na celu podjęcie przez władze optymalnych decyzji. Jest to współcześnie duże wyzwanie, które stoi przed jednostkami samorządu terytorialnego i społecznością.

Celem konsultacji społecznych jest poprawa jakości zarządzania i decyzji podejmowanych i realizowanych przez instytucje rządowe i samorządowe. Realizowane odpowiednio wcześniej, przy wykorzystaniu różnorodnych metod konsultacje pozwalają na poznanie potrzeb i problemów społeczności lokalnej, której dotyczą decyzje. Są sposobem poznania stanowisk osób i podmiotów, których skutki decyzji samorządu bezpośrednio lub pośrednio dotykają. Te skutki mogą mieć różnorodny charakter, m.in. obowiązku nałożonego na mieszkańców czy też przyznanego przywileju, prawa, udziału w realizacji przedsięwzięć i działań. Dla społeczności lokalnej konsultacje stwarzają możliwość wpływania na treść decyzji i rozwiązań, a władzy lokalnej dają możliwość poprawy jakości tych decyzji i rozwiązań. Nie są one jednak negocjacjami, gdyż, należy to podkreślić, ostateczna decyzja co do uwzględnienia uwag i opinii pozostaje w rękach władz samorządowych ${ }^{5}$. Konsultacje społeczne są więc jednym z kluczowych sposobów

5 W literaturze przedmiotu wskazuje się, że konsultacje różnią się od innych form komunikacji m.in. tym, że odpowiedzialność za kształt i treść dokumentu czy też rozwiązania poddanego konsultacji spoczywa na instytucji, która go przygotowała (autorze), a uwzględnienie uwag i opinii uzyskanych od społeczności lokalnej nie jest jego obowiązkiem. Jeśli władze samorządowe uznają te uwagi za cenne i potrzebne dla merytorycznej zawartości dokumentu lub społecznej akceptacji, to mają prawo do ich uwzględnienia. Nieuwzględnienie uwag spotyka się jednak z częstą negatywną oceną intencji instytucji (autora) przez partnerów biorących udział w konsultacjach, społeczność lokalną i może być podstawą do innych działań prawnych, administracyjnych, których celem będzie zmiana treści dokumentu czy rozwiązania. 
włączania mieszkańców w proces podejmowania decyzji i sposobów osiągania celów w polityce rozwoju lokalnego.

Ponadto pozwalają na opracowanie adekwatnych do tych potrzeb rozwiązań, a także wychwycenie błędów popełnionych na którymś z etapów planowania. Nadają one władzy samorządowej i podejmowanym przez nią decyzjom legitymizację społeczną, która jest jednym z kluczowych warunków skutecznego wdrażania polityk publicznych na szczeblu lokalnym. Służą także wyrażeniu i wymianie poglądów różnych grup w społeczności lokalnej. Udział mieszkańców w budowaniu polityk publicznych, prawa lokalnego przyczynia się do budowania wspólnoty terytorialnej i wysokiej jakości jej życia.

Konsultacje przybierają różne formy zaawansowania. W najprostszej formie konsultacje traktowane są jako forma wzajemnego informowania uczestników dialogu społecznego (wzajemne wysłuchanie się stron). W zaawansowanej formie są one elementem mechanizmów demokracji deliberatywnej, w której mieszkańcy „dochodzą do wspólnych decyzji poprzez dyskurs i debatę” (Długosz, Wygnański, 2005, s. 21).

Celem konsultacji społecznych jest poprawa jakości zarządzania w jednostkach samorządu terytorialnego i dostosowanie podejmowanych działań, planowanych rozwiązań do potrzeb społeczności lokalnej. Realizacja tych celów odbywa się poprzez dotarcie do możliwie szerokiego audytorium i zapoznanie się z jego opiniami.

Można wyróżnić ponadto bezpośrednie i pośrednie cele konsultacji organizowanych przez jednostki samorządu terytorialnego. Cele bezpośrednie, które stawiają sobie władze samorządowe, to m.in. badanie potrzeb i oczekiwań użytkowników usług publicznych, określanie priorytetów i wskazywanie preferencji mieszkańców dotyczących planowanych przedsięwzięć, ocena dostarczanych usług publicznych na terenie tej jednostki, określenie preferencji mieszkańców co do poszczególnych polityk publicznych, strategii i programów rozwoju.

Pośrednimi celami konsultacji organizowanych przez jednostki samorządu terytorialnego są m.in.: rozstrzygnięcie sporu przez samych zainteresowanych, uniknięcie lub przerzucenie odpowiedzialności za źle podjęte decyzje, konieczność przestrzegania zapisanych $\mathrm{w}$ prawie procedur konsultacyjnych, edukacja społeczności lokalnej o realizowanych przez samorząd działaniach.

Również uczestnicy konsultacji mają swoje cele i powody włączania się proces podejmowania decyzji w samorządzie lokalnym. Są one zróżnicowane i można podzielić je na trzy główne grupy:

a) cele bezpośrednie, które związane są bezpośrednio z przedmiotem konsultacji i wyrażane wprost;

b) cele pośrednie, które związane są z przedmiotem konsultacji, ale nie są wyrażane wprost;

c) powody powiązane z kontekstem, które nie są związane wyłącznie z przedmiotem konsultacji, ale z samym jego procesem (Długosz, Wygnański, 2005, s. 24-25). 


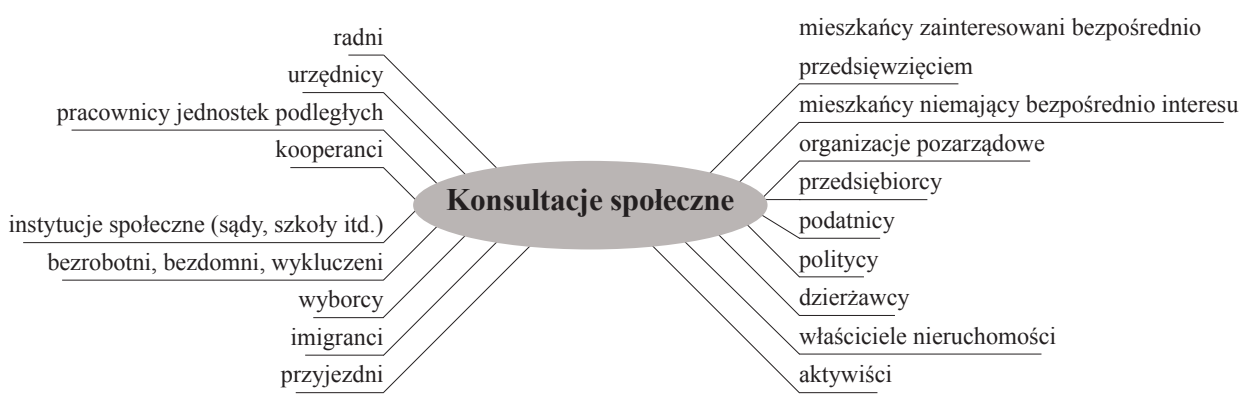

Rysunek 1. Uczestnicy procesu konsultacji społecznych

Źródło: Jak prowadzić konsultacje społeczne w samorządach?, 2010, s. 18-22

Uczestnikami procesu konsultacji społecznych jest szeroko rozumiana społeczność lokalna, czyli mieszkańcy i użytkownicy tej jednostki samorządu terytorialnego oraz ich grupy. Planując proces konsultacji, należy wziąć pod uwagę potencjalnych uczestników. W zależności od tych potencjalnych uczestników, których zaprasza się do udziału w procesie konsultacji, należy odpowiednio dostosować formy, czas, miejsce konsultacji. W społeczności lokalnej w oparciu o konkretnie przygotowane kryteria doboru uczestników konsultacji wskazać można różne grupy biorące w nich udział (rys. 1).

\subsubsection{Standardy i zasady konsultacji społecznych}

Konsultacje społeczne realizowane przez samorządy powinny spełniać co najmniej dwa określone standardy:

1) Standardy prawne, które określone są w przepisach prawa. Są to obowiązki wynikające z zapisów poszczególnych ustaw, które określają regulacje prawne w zakresie zasad i trybu przeprowadzania konsultacji w danym temacie. W ustawach tych wskazane są instytucje i organizacje mające prawo do uczestnictwa w konsultacjach, a także obowiązki organu je organizującego względem uczestników tego procesu. Ponadto wskazane są także rodzaje dokumentów, które podlegają konsultacjom, minimalny czas potrzebny na ich przeprowadzenie.

2) Standardy pozaprawne, które związane są ze społecznie akceptowanymi regułami dobrej organizacji, jakości i efektywności działania jednostek samorządu terytorialnego, a także etycznymi zasadami życia publicznego (m.in. uczciwością, dotrzymywaniem publicznych obietnic) (Długosz, Wygnański, 2005, s. 27-28).

Aby prowadzone konsultacje spełniły swoje zadanie, organizatorzy powinni zwrócić uwagę na sposób ich prowadzenia i ogólnie rozumianą jakość całego tego 
procesu. Wśród ważnych zasad prowadzenia konsultacji wymienia się dobrą wiarę, powszechność, przejrzystość, responsywność, koordynację, przewidywalność, poszanowanie dobra ogólnego i interesu publicznego.

W myśl zasady odnoszącej się do dobrej wiary konsultacje powinny przebiegać w duchu dialogu obywatelskiego. Każda ze stron powinna mieć prawo wypowiedzenia się, a druga obowiązek jej wysłuchania. Ponadto strony powinny wyrażać wolę zrozumienia odmiennych poglądów innych stron. Organizacja konsultacji powinna zakładać jasny, rzetelny i przystępny sposób prezentacji przedmiotu konsultacji. Każdy z uczestników procesu konsultacji powinien wykazywać gotowość do zmiany swojego stanowiska i modyfikacji pomysłów (organizator - gotowość na krytyczne uwagi, wprowadzenie korekt i zmian, uczestnicy - gotowość zmiany zdania w oparciu o przekonujące argumenty). Organizator powinien w jasny i zrozumiały sposób określić czas trwania i termin zgłaszania uwag i opinii. Odpowiednio zaplanowany czas trwania konsultacji powinien dać uczestnikom możliwość zgromadzenia potrzebnych materiałów, argumentów i przygotowanie uwag i opinii dotyczących przedmiotu konsultacji.

Zasada powszechności odnosi się do możliwości uczestnictwa w konsultacjach. Każdy zainteresowany przedmiotem konsultacji powinien mieć możliwość dowiedzenia się o konsultacjach i wyrażenia swojej opinii. Organizator konsultacji zobowiązany jest do poinformowania o rozpoczęciu konsultacji w miejscu ogólnodostępnym (BIP, strona internetowa, przeznaczona do konsultacji platforma internetowa) oraz formacie umożliwiającym przeszukiwanie dokumentu. $\mathrm{Na}$ organizatorze spoczywa także obowiązek aktywnego docierania do zainteresowanych mieszkańców jednostki samorządu terytorialnego, zwłaszcza grup, które nie korzystają z dostępnych, nowoczesnych źródeł informacji (m.in. Internet). Do udziału w konsultacjach powinny zostać zaproszone osoby z opracowanej publicznej listy interesariuszy. Ponadto, przedmiot konsultacji powinien być zaprezentowany w jasny i zrozumiały sposób dla zainteresowanych nim mieszkańców.

Zasada przejrzystości zapewnia uczestnikom konsultacji dostęp do informacji o celu, zasadach i regułach, planowanym przebiegu i wyniku konsultacji. Jawne i powszechnie dostępne powinny być informacje m.in. o harmonogramie, zgłoszonych uwagach i odpowiedziach na uwagi. Poza tym musi być jasno określone, kto reprezentuje jaki pogląd, czyli zgłaszane uwagi powinny mieć podanego autora, chyba że organizator konsultacji w regulaminie dopuści możliwość zgłaszania opinii anonimowych. Podkreślić należy, że zamkniętych spotkań z ekspertami nie traktuje się jako konsultacji.

Zasada responsywności zakłada, że każdemu uczestnikowi konsultacji należy się merytoryczna odpowiedź w rozsądnym i akceptowalnym terminie. Powinien zostać określony termin podsumowania konsultacji, a samo podsumowanie zawierające zgłoszone uwagi i uzasadnienie podjętych przez samorząd decyzji powinno zostać opublikowane na ogólnodostępnym portalu. Po stronie organi- 
zatora leży przygotowanie uzasadnienia, które będzie czytelne i jasne dla mieszkańców (m.in. napisane prostym i zrozumiałym językiem) i dopilnowanie, aby o wynikach konsultacji dowiedziały się wszystkie osoby, które zgłosiły swoje propozycje uwag i opinie.

Zasada koordynacji wskazuje konieczność określenia gospodarza konsultacji, który odpowiedzialny jest za cały proces i pełni istotne funkcje decyzyjne w zależności od zasięgu i przedmiotu konsultacji (prezydent, wójt, burmistrz, dyrektor wydziału lub departamentu w urzędzie). Osoba ta ma obowiązek włączać w proces konsultacji podległą jej administrację. Gospodarz ma możliwość wyznaczenia koordynatora konsultacji (dyrektor wydziału, naczelnik lub organizacja pozarządowa, której zlecono przeprowadzenie konsultacji), jednak należy o tym poinformować uczestników procesu.

Zasada przewidywalności zakłada planowość i czytelne reguły prowadzenia procesu konsultacji. Konsultacjami nie są spotkania, podczas których akceptacji poddaje się podjęte już wcześniej decyzje władz samorządowych. Optymalny czas trwania tego procesu to nie mniej niż 21 dni dla każdego etapu, co daje uczestnikom czas na odpowiednie przygotowanie się i zebranie opinii. Nie można nazwać konsultacjami społecznymi czasu krótszego niż 7 dni, przeznaczonego na zbieranie opinii. W harmonogramie konsultacji należy przewidzieć i zaplanować czas na rozpatrzenie uwag i opinii i przygotowanie do nich stosownych odpowiedzi. Należy pamiętać także o tym, że konsultacji nie powinno się rozpoczynać w sytuacji trwania jawnego konfliktu w danej sprawie. Rozpoczęte na odpowiednio wczesnym etapie planowania i rzetelnie przygotowane konsultacje mają zapobiec powstaniu ewentualnych konfliktów. Ważne jest również, aby termin przydzielony na sformułowanie opinii na każdym etapie prac był nie krótszy niż 21 dni oraz aby harmonogram konsultacji zakładał czas na rozpatrywanie opinii oraz opracowanie odpowiedzi.

Zasada poszanowania dobra ogólnego i interesu publicznego zakłada, że organizator konsultacji przy podejmowaniu decyzji kieruje się interesem publicznym, a nie interesem poszczególnych grup uczestników i siłą ich nacisku. Założeniem przyświecającym konsultacjom jest obustronne wysłuchanie zgłaszanych racji (Siedem Zasad Konsultacji, 2013).

Do zasad prowadzenia konsultacji opracowanych przez instytucje rządowe, na które powołują się jednostki samorządu terytorialnego, można dodać zasadę ciągłości i sprzężenia zwrotnego, co oznacza, że proces konsultacji ma charakter ciągły. Jest to proces zaplanowany, nastawiony na osiągnięcie zamierzonych i zdeklarowanych jasno celów. Konsultacje nie powinny być realizowane pod wpływem chwili czy też żądań jakiś grup społeczności lokalnej (,wymuszanie konsultacji”), czy też narastających napięć.

Ponadto ważne jest, aby cały proces był dokumentowany. Zainteresowani uczestnicy konsultacji powinni mieć wgląd do tych dokumentów, móc odwoływać 
i wnioskować o ich korektę zgodnie ze stanem faktycznym, który miał miejsce podczas konsultacji. Uczestnicy konsultacji mają prawo spodziewać się odpowiedzi i uzasadnienia przyjęcia lub odrzucenia zgłoszonych uwag i opinii zarówno w trakcie debaty, jak i w czasie jej podsumowania. Wartością wynikającą z podsumowania i refleksji po zakończonych konsultacjach powinny być zebrane doświadczenia i wnioski, które pozwolą na poprawę jakości standardów realizowanych w przyszłości przedsięwzięć i konsultacji społecznych.

Partycypacja społeczna i najczęściej z nią kojarzone konsultacje społeczne są bardzo różnie rozumiane przez samorządy w Polsce. Zastosowanie niejednakowych instrumentów partycypacyjnych zależy od sposobu postrzegania tego procesu, potrzeby, a także celów, jakie przedstawiciele samorządu chcą w tym procesie osiągnąć. Samorządy stosują współpracę z partnerami społecznymi w różnych formach, począwszy od formalnych rozmów z odwiedzającymi urząd mieszkańcami, przedstawicielami organizacji pozarządowych, udział przedstawicieli samorządu w zebraniach wiejskich, kończąc na organizowaniu debat publicznych i konsultacji z mieszkańcami. Są to jednak klasyczne formy udziału w życiu wspólnoty terytorialnej. W wielu jednostkach funkcjonują stałe grupy wymiany opinii lub grupy robocze o charakterze konsultacyjnym.

Konsultacje społeczne mają charakter zarówno obligatoryjny, jak i fakultatywny. Na samorządzie terytorialnym spoczywa obowiązek uwzględnienia udziału społeczności lokalnej w procesach decyzyjnych, które dotyczą m.in.: planowania przestrzennego, oddziaływania planowanych inwestycji na środowisko. Obowiązek ten wynika z przepisów ustaw wskazanych we wcześniejszym rozdziale. Pozostałe kwestie dotyczące funkcjonowania wspólnoty terytorialnej mogą, ale nie muszą być poddawane konsultacjom. Ważne, aby decyzja jednostek samorządu terytorialnego co do ich organizacji wynikała z potrzeby i korzyści będących rezultatem udziału społeczności w procesie decyzyjnym. Ważne także, aby była to decyzja przemyślana, a konsultacje profesjonalnie przygotowane. Nieprzygotowane czy też źle poprowadzone konsultacje społeczne mogą mieć poważne konsekwencje społeczne i skutecznie zniechęcić społeczność lokalną do współdecydowania na wiele lat, a także mogą prowadzić do pojawienia się lub wzmocnienia konfliktów społecznych i politycznych.

W procesie konsultowania realizowane są działania mające wpływ na edukację obywatelską, co przejawia się w pobudzaniu ogólnej aktywności mieszkańców w życiu publicznym społeczności lokalnej, następuje identyfikacja mieszkańców z działaniami realizowanymi przez samorząd. Działania te mają także wpływ na budowanie kapitału społecznego w środowisku lokalnym oraz budowanie poczucia współodpowiedzialności za wspólnotę lokalną.

Konsultacje budują również partnerską współpracę, gdyż są mechanizmem tworzenia przestrzeni kontaktu i budowania wzajemnych powiązań między przedstawicielami samorządu lokalnego i lokalnymi podmiotami społeczno- 
-gospodarczymi. Sprzyjają nawiązywaniu bezpośredniego dialogu, a także minimalizacji negatywnego wpływu stereotypów i braku wzajemnego zaufania.

Konsultacje społeczne pozwalają samorządom skutecznie i trafnie identyfikować rzeczywiste potrzeby mieszkańców. Sprzyjają wymianie pomysłów, opinii o proponowanych przez samorząd rozwiązaniach, a przede wszystkim wypracowaniu wspólnego w społeczności lokalnej stanowiska - konsensusu. W procesie konsultacji niwelowane są napięcia i konflikty związane z planowanymi decyzjami czy też przedsięwzięciami, a także ustala się priorytety działań zgodnych z rzeczywistymi potrzebami mieszkańców.

W procesie konsultacji społecznych następuje bezpośrednia konfrontacja oczekiwań ze strony mieszkańców z aktualnymi możliwościami realizacyjnymi samorządów (Jak prowadzić konsultacje spoteczne w samorządach, 2010, s. 47).

\subsubsection{Nowoczesne formy konsultacji społecznych}

W procesie konsultacji społecznych wykorzystuje się różne metody i techniki ich prowadzenia. Aby osiągnąć zamierzony cel konsultacji należy je prawidłowo zaplanować, a następnie przeprowadzić.

Każda z metod stosowanych w konsultacjach posiada swoje wady i zalety i powinna być stosowana w zależności od przyjętego celu oraz od zakładanej grupy odbiorców. Obecnie stosuje się już wiele metod i technik konsultacji w Polsce. Do najpopularniejszych należą: spotkania publiczne, wysłuchania publiczne, pisemne opiniowanie, wykorzystanie grup przedstawicielskich, e-konsultacje, grupy fokusowe, wywiady kwestionariuszowe, panele obywatelskie, dni otwarte, pokazy uliczne, prezentacje, samorządowy informator SMS. Metody te i techniki z uwagi na ich dość powszechny charakter i wykorzystanie oraz szeroki opis w literaturze przedmiotu nie będą przedmiotem niniejszego rozdziału.

Dodatkowo, coraz częściej wykorzystywane są bardziej zaawansowane metody i techniki konsultacji. Należą do nich m.in. warsztaty Charrette, sondaż deliberatywny, planowanie partycypacyjne, Future City Game, Miejskie Spotkanie XXI Wieku (Century Town Meeting), Otwarta Przestrzeń (Open Space), komórki planujące, Sąd Obywatelski, Planning For Real, City Sourced, Word Cafe.

\section{a) Sondaż deliberatywny}

Metoda pojawiła się w polskiej praktyce w 2012 r. w Poznaniu. Jej opracowanie i pierwsze zastosowanie miało miejsce pod koniec lat 80. na Uniwersytecie Stanforda w Stanach Zjednoczonych. Sondaż deliberatywny prowadzony jest w kilku etapach. Podstawowym założeniem jest połączenie dwóch metod: spotkania 
grupowego oraz sondażu. Pierwszym etapem jest opracowanie możliwie bezstronnych materiałów prezentujących dostępne rozwiązania dla przedmiotu konsultacji. Materiały te przygotowywane są przy współpracy władz lokalnych i grup zainteresowanych, np. organizacji pozarządowych. Następnie przeprowadzany jest na ich podstawie sondaż na reprezentatywnej grupie uczestników. Kolejnym krokiem jest wybór spośród uczestników sondażu grupy osób (stanowi ona około 30\%), która weźmie udział w kolejnym etapie, czyli w publicznej debacie. Uczestnicy tego etapu otrzymują materiały dotyczące alternatywnych rozwiązań, z którymi mają się zapoznać, a następnie udają się na 1-2-dniową wspólną sesję, podczas której następuje omówienie metody pracy. Następnie uczestnicy dzieleni są na mniejsze grupy, moderowane przez profesjonalnych moderatorów. Moderatorzy dbają o określony przebieg i charakter dyskusji, a także aby każdy z uczestników miał możliwość zabrania głosu. W pracach grup mogą uczestniczyć zaproszeni eksperci i decydenci, jednak ich rolą jest odpowiadanie na zadane pytania, a nie przekonywanie do wyboru określonego rozwiązania. Następnie uczestnicy ponownie spotykają się na wspólnej sesji, gdzie omawiane i dyskutowane są efekty pracy w grupach. Ostatnim etapem sondażu deliberatywnego jest głosowanie tajne, w którym uczestnicy wyrażają swoje preferencje co do zaproponowanych rozwiązań. Zdarza się ponadto, że w niektórych przypadkach wykonuje się dodatkowo jeszcze ponowne badanie sondażowe wśród osób, które brały udział w pierwszym sondażu, a nie brały udziału w publicznej debacie. Główną cechą sondażu deliberatywnego jest poznanie rozkładu opinii dotyczących wybranego zagadnienia. Założeniem jest zapewnienie uczestnikom pełnego dostępu do informacji. Nie jest to metoda wypracowania wspólnego rozwiązania (konsensusu), co powoduje, że ostateczny wynik nie jest wiążący dla władz samorządowych.

Dobra praktyka. Pierwszy sondaż deliberytywny w Polsce został przeprowadzony w Poznaniu i dotyczył kwestii zarządzania stadionem miejskim przy ul. Bułgarskiej. Uczestnikom sondażu przedstawiono cztery możliwe rozwiązania:

a) powierzenie zarządzania stadionem klubowi KKS Lech;

b) powierzenie zarządzania instytucji w rodzaju POSiR;

c) powierzenie niezależnemu operatorowi zarządzania częścią komercyjną (obiekty komercyjne na stadionie i w jego najbliższym otoczeniu) stadionu;

d) powierzenie zarządzania całym kompleksem sportowo-rekreacyjnym włącznie ze stadionem i jego otoczeniem.

Sondaż deliberatywny został zorganizowany i sfinansowany przez Projekt Społeczny 2012, który realizowany jest przez Instytut Socjologii Uniwersytetu Warszawskiego ze środków grantu otrzymanego od Trust for Civil Society in Central and Eastern Europe przy wsparciu ze strony Centrum Demokracji Deliberatywnej Uniwersytetu Stanforda oraz Urzędu Miasta Poznania (Przybylska, 2014, s. 121-137). 


\section{b) Warsztaty Charrette}

Warsztaty Charrette to forma pracy zespołowej. Nazwa Charrette pochodzi od nazwy małych wózków używanych pod koniec XIX w. przez asystentów pracujących na Akademii Sztuk Pięknych w Paryżu do zbierania prac na koniec egzaminów. Metoda Charrette stała się popularna w latach 70. XX w. w Stanach Zjednoczonych i używana była do prowadzenia warsztatów urbanistycznych. Warsztaty te oparto na projektowaniu otwartym i realizowanym przy współudziale wielu uczestników. Są one przeznaczone zarówno dla władz lokalnych oraz mieszkańców, jak i ekspertów, planistów czy przedstawicieli organizacji pozarządowych, co pozwala uniknąć wielu sporów przy uzgodnieniach na późniejszym etapie inwestycji oraz ogranicza ewentualne protesty mieszkańców i lokalnych społeczności. Warsztaty polegają na wspólnej pracy wszystkich uczestników wytwarzania przestrzeni miejskiej (urbanistów, mieszkańców, developerów, inwestorów). Zakładają one ścisłą współpracę aktorów nad stworzeniem takiej wizji przestrzeni miejskiej, która uwzględnia interesy wszystkich jej użytkowników. Jednym z podstawowych celów tej metody jest wypracowanie konsensusu, czyli wypracowanie planu działania poprzez wymianę pomysłów oraz uzgodnienie wspólnego stanowiska dla wszystkich uczestników. Tematem ustaleń wypracowywanych podczas warsztatów są najczęściej kwestie dotyczące planowania nowych osiedli, rewitalizacji, odnowy przestrzeni publicznych czy też rewitalizacji centrów miejskich. Obecnie, metoda ta staje się coraz powszechniejsza w Europie - także w Polsce. Metoda ta sprawdza się nawet w sytuacjach konfliktowych. Najczęściej tematem warsztatów stają się te związane z zagospodarowaniem przestrzennym, projektami urbanistycznymi i rewitalizacyjnymi, jednak formuła warsztatów pozwala na stosowanie tej metody także do konsultacji w innych tematach. Najczęściej warsztaty przebiegają w postaci skoncentrowanych sesji trwających niejednokrotnie wiele dni. Dzięki dużemu zróżnicowaniu uczestników oraz współpracy między nimi warsztaty pozwalają na stworzenie realistycznych rozwiązań. Warsztaty takie pomagają także budować wzajemne zaufanie podmiotów uczestniczących w procesie konsultacji społecznych. Dzięki temu opracowane projekty są akceptowane przez uczestniczących w procesie podejmowania decyzji mieszkańców jednostki samorządu terytorialnego. Warsztaty przybierają najczęściej formę wielkiej, wieloetapowej debaty publicznej, która może być stosowana zarówno w fazie projektowej, jak i decyzyjnej. Bardzo cennym elementem warsztatów Charrette są wizje terenowe, które realizowane są w celu lepszego poznania przedmiotu konsultacji. Przykładami są warsztaty zrealizowane w Konstancinie-Jeziornie, Siewierzu, Będzinie, Gdyni, Częstochowie, Dąbrowie Górniczej, Katowicach.

Dobra praktyka. Warsztaty Charrette w Konstancinie-Jeziornie dotyczyły legendarnej papierni, mieszczącej się w dzielnicy Konstancina-Jeziornej - Mirkowie. Dzięki tej metodzie władze samorządowe postanowiły rozwiązać narastający 
konflikt pomiędzy mieszkańcami osiedla a władzami gminy i właścicielem spółki, która przenosi produkcję papieru na drugi koniec Polski. Pierwszym krokiem było pogłębione interdyscyplinarne studium terenu objętego przyszłym planowaniem. Drugi etap polegał na zintensyfikowaniu udziału społeczności lokalnej we wspólnej pracy nad nowym projektem adaptacji. W tym etapie uczestniczyli eksperci, analitycy, planiści, rysownicy, właściciele, inwestorzy, decydenci, radni, przedstawiciele stowarzyszeń, wspólnot mieszkaniowych i mieszkańcy.

Warsztaty Charrette zostały zastosowane także w Częstochowie w 2012 r. Organizatorami warsztatów były władze samorządowe, a przedmiotem tych konsultacji - prace nad rewitalizacją Starego Miasta w Częstochowie. Trzydniowa sesja zachęcić miała mieszkańców do uczestnictwa w procesie decyzyjnym nad rewitalizacją częstochowskiej starówki. W wyniku warsztatów wypracowano rozwiązania mające na celu uszczegółowienie planu rewitalizacji dla dzielnicy. W spotkaniach otwartych wzięło udział przeszło 100 osób, w tym: właściciele nieruchomości i mieszkańcy dzielnicy, pracownicy szkół i uczelni, przedsiębiorcy, radni, posłowie, przedstawiciele stowarzyszeń, projektanci oraz władze lokalne. Prace były podzielone na sześć etapów. Podczas warsztatów określono główne problemy i bariery rozwoju dzielnicy, a także wspólnie zbudowano wizję jej rozwoju na najbliższe lata. Opracowane zostały zintegrowane projekty. Następnie wyniki zrealizowanego badania ankietowego pozwoliły na określenie elementów koncepcji zagospodarowania przestrzennego tej dzielnicy. Ponadto podczas warsztatów przygotowano propozycję przedsięwzięć, których realizatorami mieli być m.in. uczestnicy spotkań warsztatowych. Zostały one poddane wspólnie weryfikacji, a także ocenie pod względem ważności dla dzielnicy. Efektem warsztatów było m.in. wyłonienie szczegółowych projektów i przedsięwzięć do dalszego opracowania, a następnie wdrażania (Basaj, 2013, s. 279-288).

\section{c) Planowanie partycypacyjne}

Technika planowania partycypacyjnego służy wspólnemu budowaniu dokumentów, decydowaniu o kształcie przestrzeni jednostki samorządu terytorialnego (programy rewitalizacji, strategie rozwoju, plan miejscowy, budowa instytucji publicznych, projektowanie przestrzeni itp.). Jest to dłuższy proces składający się z kilku elementów. Najczęściej wskazuje się trzy jego zasadnicze części. Pierwszą z nich jest szczegółowa analiza i diagnoza sytuacji wyjściowej jednostki samorządu terytorialnego, którego ona dotyczy. Etap ten polega na przeprowadzeniu badań społecznych i analizie danych wtórnych, dotyczących m.in. zasobów, zainteresowanych grup społeczności lokalnej i jej interesów, wizji lokalnej. Drugą część stanowi organizacja spotkań i warsztatów, których celem jest zaprojektowanie we współpracy z uczestnikami tego procesu konkretnych rozwiązań. Mogą to być spotkania i warsztaty ze specjalistami z zakresu gospodarki przestrzennej, architektami, urbanistami, podczas których wypracowywane są rozwiązania przestrzenne, wizje i koncepcje rozwoju jednostki samorządu terytorialnego. 
Drugi etap wymaga wiedzy eksperckiej oraz znajomości zagadnień poruszanych w pierwszym etapie. Następnie na podstawie zaproponowanych rozwiązań eksperci z przedstawicielami jednostki samorządu terytorialnego lub z zespołem badawczym przygotowują różne warianty koncepcji, które będą ostatecznie ponownie dyskutowane ze społecznością lokalną. Ostatnim etapem jest dyskusja nad przygotowanymi koncepcjami i podjęcie wspólnej decyzji - konsensusu w sprawie jednego rozwiązania.

Jedno z pierwszych zastosowań w Polsce techniki planowania partycypacyjnego miało miejsce przy projektowaniu zagospodarowania Osiedla Cytadela Południowa na Żoliborzu w Warszawie, a także przy projektowaniu i konsultacji koncepcji Parku Kaskada także na Żoliborzu. Podobne zastosowanie tej techniki miało miejsce w ramach projektu "Wzmacnianie mechanizmu partycypacji społecznej w m.st. Warszawie", którego przedmiotem było zagospodarowanie terenu w dzielnicach: Ochota, Śródmieście, Wesoła (Przewodnik po partycypacji spotecznej, 2005, s. 47-58).

\section{d) Future City Game}

Technika Future City Game została opracowana w Wielkiej Brytanii, w ramach projektu British Council „Creative Cities”. Służy ona do tworzenia wspólnej i kompleksowej wizji rozwoju danego miejsca, a także aktywizacji społeczności lokalnej. Tematem Future City Game są najczęściej kwestie zagospodarowania przestrzeni, rewitalizacja lub sposoby funkcjonowania miejsca. Polega ona na tym, że podczas jedno- lub dwudniowego spotkania zaproszeni przedstawiciele społeczności lokalnej (mieszkańcy, przedsiębiorcy, zewnętrzni specjaliści, przedstawiciele organizacji pozarządowych i administracji) wraz z moderatorem spotkania tzw. ,mistrzem gry” wypracowują konkretne rozwiązania przestrzenne i funkcjonalne dla danego miejsca lub problemu powiązanego $\mathrm{z}$ tym miejscem (np. oferta domu kultury). W warsztatach bierze udział zazwyczaj około 25 osób, które podzielone są na 3-4 grupy. Są one najczęściej elementem procesu planowanych zmian, stąd też potrzeba ich organizacji na stosunkowo wczesnym etapie. Warsztaty przebiegają według dziesięcioetapowej procedury. Pierwszym krokiem jest analiza problemów na poziomie globalnym i lokalnym, które dotykają społeczność lokalną, oraz gospodarczych, społecznych, ekologicznych i kulturowych perspektyw rozwoju tego obszaru. Kolejnym krokiem jest generowanie pomysłów na przyszłość. Następnie wygenerowane pomysły są testowane w terenie przy pomocy specjalistów, mieszkańców, turystów, urzędników i obserwatorów. Kolejnym krokiem jest prezentacja na forum ostatecznych koncepcji wypracowanych w grupach. Ostatnim etapem jest ocena opracowanych rozwiązań przez graczy i obserwatorów i wybór najlepszego projektu. Future City Games jest techniką dość czasochłonną, ale nie wymaga dużych nakładów finansowych. Pierwszy raz zastosowano ją w Polsce przy projektowaniu koncepcji funkcjonowania dzielnicy 
Księży Młyn w Łodzi oraz Grze Miasta Przyszłości w Gdańsku (ożywienie i poprawa wizerunku podwórzy historycznego centrum miasta) w ramach projektu „Miasta Kreatywne British Council”. Metodę wykorzystano również przy projektowaniu przyszłości funkcjonowania ulicy Piotrkowskiej w Łodzi, zagospodarowania ulicy Samborskiej w Warszawie, a także w ramach projektu „Wzmacnianie mechanizmu partycypacji społecznej w m.st. Warszawie" (Przewodnik po partycypacji społecznej, 2005, s. 47-58).

\section{e) Sąd Obywatelski}

Technika nazywana Sądem Obywatelskim (ang. citizens jury) służy identyfikacji prawdziwych potrzeb i rozwiązań odpowiadających na te potrzeby, a także wyborowi rozwiązań lub formułowaniu opinii dotyczących kontrowersyjnych i złożonych spraw. Wymaga ona pracy z reguły niewielkiej liczby osób (mieszkańców, obywateli, użytkowników), którzy jednocześnie nie są ekspertami ani nie są bezpośrednio zaangażowani $\mathrm{w}$ tę sprawę. Sąd Obywatelski przypomina rozprawę sądową, gdzie wzorem sądów amerykańskich pracują ławnicy sądowi, którzy słuchają stron postępowania, świadków, rozpatrują złożoność całej sprawy, przedstawiane argumenty, a następnie wydają ostateczny werdykt. Technika ta ma przynieść konstruktywny wkład obywateli, co pozwoli urzędnikom samorządowym dokonać niejednokrotnie trudnych wyborów. Ważną rolę Sądu Obywatelskiego upatrywać można w przyciąganiu mediów, a także w budowaniu wzajemnego szacunku i umiejętności prowadzenia dyskusji. Ten sposób partycypowania mieszkańców w podejmowaniu decyzji i wypracowywaniu najlepszych rozwiązań dla mediów wydaje się być niezwykle atrakcyjny, dzięki czemu uwaga opinii publicznej skoncentrowana jest właśnie na omawianych sprawach, a informacje docierają do większej liczby mieszkańców (Citizens Jury Handbook, s. 3-9).

Skład sędziów-ławników odzwierciedla skład społeczności lokalnej, jakiej dotyczy sprawa (próba reprezentatywna). Skład sędziowski liczy najczęściej około 12-16 osób. Wybranymi do tego składu osobami są zwykli mieszkańcy, którzy reprezentują różne środowiska i grupy społeczne w tej społeczności. Jurorzy (sędziowie) obradują od dwóch do czterech, a nawet pięciu dni, podczas których uzyskują informacje, materiały opisujące różne sposoby rozwiązania danego problemu, zadają pytania i słuchają zaproszonych ekspertów, pełniących rolę świadków. Metoda ta wymaga uczestnictwa ekspertów z danej dziedziny oraz zaangażowania osoby pomagającej składowi sędziowskiemu w moderacji spotkania. Czas odpowiedniego zaplanowania i przygotowania całego procesu to najczęściej dwa do trzech miesięcy.

Celem sądu nie musi być dążenie do wypracowania formalnego konsensusu. W wielu przypadkach chodzi o samo ścieranie się różnych poglądów, poznanie argumentacji i racji różnych stron sporu. Metoda ta więc nie służy do podejmowania i formalizowania decyzji w sprawach konfliktowych, a bardziej ma wspomóc 
jednostkę samorządu terytorialnego w wyborze rozwiązania czy też wskazania decyzji, którą samorząd powinien podjąć.

Metoda Sądu Obywatelskiego została opracowana w latach 90. i była wielokrotnie wykorzystywana głównie na szczeblu lokalnym w samorządach w Europie i Ameryce. W Niemczech (Hanower) służyła przy reformie systemu transportu miejskiego, w Wielkiej Brytanii (Lavenmouth) przy wprowadzaniu zmian w opiece dla osób nieuleczalnie chorych oraz przy opracowaniu polityki przeciwdziałania zażywaniu narkotyków oraz jego społecznym skutkom (Lewisham). Metodę tę stosuje się coraz częściej w sprawach nie tylko o charakterze lokalnym, ale także regionalnym lub ogólnokrajowym (Przewodnik po partycypacji społecznej, 2005, s. 47-58; Citizens Jury Handbook, s. 3-9).

\section{f) City Sourced}

City Sourced to jedna z technik partycypacyjnych wykorzystująca nowe technologie teleinformacyjne. Są to systemy umożliwiające zgłaszanie nietypowych sytuacji i zjawisk, awarii bezpośrednio przez każdego, kto zaobserwuje w swojej okolicy coś dziwnego. Systemy te wykorzystują popularne telefony komórkowe typu „smartphone”, dzięki którym mieszkańcy wykonują i przesyłają zdjęcia sytuacji, zjawisk, aktów wandalizmu $\mathrm{z}$ adnotacją do wskazanych pracowników sektora publicznego. Utrudnieniami w wykorzystaniu tych systemów jest konieczność posiadania telefonu komórkowego typu „smartphone”, ale także zainstalowanie odpowiedniej, darmowej aplikacji. Systemy takie stosowane są głównie w miastach amerykańskich (Sam Jose oraz San Francisco w stanie California, USA) (Przewodnik po partycypacji społecznej, 2005, s. 47-58).

\section{g) World Cafe}

The World Cafe ogólnoświatowy ruch działający na rzecz rozmów wśród środowisk biznesowych, środowisk organizacji pozarządowych, społeczności lokalnych oraz sektora publicznego na całym świecie opracował różnego rodzaju narzędzia służące budowaniu żywego dialogu i współpracy. Narzędzia te mają na celu generowanie pomysłów, upowszechnianie wiedzy i informacji, pobudzanie kreatywnego myślenia w ważnych dla danej społeczności sprawach (Rozmowy w Kawiarence. Przewodnik krok po kroku, jak z rozmowy zrobić narzędzie, 2012, s. 2-8).

W World Cafe może uczestniczyć od parunastu do nawet 1200 osób, które w przyjaznej i bardzo luźnej atmosferze, przypominającej kawiarniany klimat, omawiają ważne dla siebie kwestie. W zależności od wybranego tematu i liczby uczestników sesja kawiarniana trwa najczęściej około 2-3 godzin. W tej metodzie niezwykle ważny jest klimat i miejsce, które sprzyjać ma prowadzeniu nieformalnych i mało oficjalnych rozmów odwołujących się do własnych doświadczeń, a nie ogólnodostępnej wiedzy na dany temat. Spotkania World Cafe odbywają się w kawiarniach lub miejscach, gdzie tworzona jest kawiarniana atmosfera (stoliki kawiarniane, kolorowe obrusy, napoje, delikatna, chilloutowa muzyka w tle, która 
nie zagłusza i nie dekoncentruje uczestników, flipcharty, pisaki, arkusze papieru do pisania i rysowania, drobne przekąski itp.).

Uczestnicy World Cafe dzieleni są na mniejsze kilkuosobowe grupy, które przy stolikach dyskutują na zadany wcześniej inny temat. Każdy stolik posiada gospodarza pełniącego rolę moderatora. Co pewien czas (np. co 20-30 min) grupy zmieniają stolik. Gospodarz pozostaje przy swoim stoliku, a następnie po zmianie grupy referuje nowej grupie, co powiedzieli ich poprzednicy i zachęca do dalszej dyskusji. Podczas pracy w grupach uczestnicy zapisują bądź rysują swoje pomysły, uwagi na kolorowych kartkach lub papierowych obrusach tak, aby następni uczestnicy mogli się do tego odwołać i w razie potrzeby uzupełnić. Na koniec odbywa się sesja plenarna, gdzie gospodarze stolików podsumowują dyskusje, które odbywały się przy stolikach. Końcowa sesja służy wskazaniu uczestnikom nowych odkryć i pomysłów, które powstały z pojedynczych uwag i idei.

World Cafe jest metodą służącą prowadzeniu dialogu, pobudzaniu kreatywności, dzieleniu się doświadczeniem i wiedzą, stąd też warto stosować ją nie tylko do dyskutowania konkretnych rozwiązań, ale także w początkowych fazach procesu partycypacji, aby zaproszeni uczestnicy mogli poznać swoje potrzeby i oczekiwania (Przewodnik po partycypacji spotecznej, 2005, s. 47-58).

\section{h) Kawiarnia Obywatelska}

Metoda nazywana Kawiarnią Obywatelską (ang. Conversation Cafe) związana jest z omówioną już metodą World Cafe. Jest ona jednak luźniejsza w swojej formule i przeznaczona dla mniejszej liczby uczestników. Jest nastawiona na dia$\log$ między uczestnikami, który jest celem samym w sobie. Kawiarnia Obywatelska przypomina w swojej formule nieformalne spotkanie, podczas którego grupa 8-10 osób dyskutuje na ważny dla nich temat. Miejscem może być kawiarnia lub inna przestrzeń, gdzie tworzona jest kawiarniana atmosfera (stoliki kawiarniane, kolorowe obrusy, napoje, delikatna muzyka w tle, która nie zagłusza i nie dekoncentruje uczestników). Temat spotkania w ramach Kawiarni Obywatelskiej może być dowolny, ale warto podkreślić, że metoda ta nie służy podejmowaniu konkretnych decyzji, bardziej służy poznaniu się uczestników, wymianie myśli, opinii i doświadczeń. Często jest także świetnym narzędziem inspirującym uczestników do działania (por. Kawiarenka Obywatelska, www.stowarzyszenieamicus.org).

W Kawiarni Obywatelskiej może brać udział każda osoba zainteresowana tematem. Spotkanie trwające najczęściej 1-2 godziny prowadzi moderator w oparciu o przygotowany wcześniej schemat. Najczęściej przebiega ono w następujący sposób. Na samym początku moderator przedstawia zasady, których powinni przestrzegać uczestnicy (otwartość, akceptacja, ciekawość, odkrycie, szczerość i zwięzłość) $^{6}$ oraz prosi o wypowiedź każdego uczestnika (przedstawienie się oraz kilka

${ }^{6}$ Zasada otwartości dotyczy wysłuchania i poszanowania dla innych uczestników. Zasada akceptacji odnosi się do powstrzymania od oceny innych. Zasada ciekawości mówi o zrozumieniu 
zdań o temacie spotkania). Następnie, gdy wszyscy się poznają, można odnieść się do wcześniejszych wypowiedzi. Po zakończeniu tej rundy moderator otwiera właściwą część dyskusji, podczas której uczestnicy w dowolnej kolejności wypowiadają się i odnoszą się do podanych wcześniej argumentów. Jest to najdłuższa część spotkania. Ostatnią zainicjowaną przez prowadzącego dyskusją jest końcowa runda, w której uczestnicy po kolei mówią, co z niej wynieśli i co było dla nich ważne.

\subsection{Budżet partycypacyjny}

Jednym z najbardziej popularnych w ostatnich paru latach w Polsce instrumentów partycypacji społecznej w zintegrowanym zarządzaniu jednostkami samorządu terytorialnego jest budżet partycypacyjny (obywatelski). Udało się go wprowadzić w ponad siedemdziesięciu gminach i miastach w Polsce. Budżet partycypacyjny określany jest jako „proces decyzyjny, w ramach którego mieszkańcy współtworzą budżet danego miasta, współdecydując tym samym o dystrybucji określonej puli środków publicznych" (Kębłowski, 2013, s. 8). Budżet partycypacyjny służy zaangażowaniu mieszkańców do współtworzenia budżetu związanego z obszarem, który zamieszkują lub w którym bezpośrednio funkcjonują. Teoretycznie $w$ ramach budżetu obywatelskiego mogą być realizowane wszystkie projekty, które wpisują się w katalog zadań własnych gminy (lub odpowiednio powiatu, województwa). Praktycznie natomiast wiele jednostek samorządu terytorialnego ogranicza możliwość zgłaszania projektów do wybranych obszarów funkcjonowania samorządu.

Władze samorządowe za pomocą budżetu partycypacyjnego mają dodatkową możliwość wprowadzania zmian w realizowanej polityce miejskiej poprzez m.in. inicjowanie i wzmacnianie zaangażowania mieszkańców oraz umożliwienie im uczestnictwa w procesie decyzyjnym. Takie działania przyczyniają się do budowania społeczeństwa obywatelskiego w Polsce. Metoda ta pozwala również zwiększyć przejrzystości zarządzania środkami publicznymi (Pyka, 2011, s. 47-58).

\subsubsection{Zasady i procedury}

Proces budowania i realizacji budżetu obywatelskiego składa się z kilku etapów. Proces wprowadzania budżetu obywatelskiego z uwagi na brak ścisłych uregulowań prawnych oraz dużą dowolność i elastyczność pozostawioną jednostkom

racji innych, a nie przekonywaniu innych do swoich racji. Zasada odkrycia związana jest z poszukiwaniem nowych informacji i rozwiązań. Zasada szczerości zachęca do mówienia o tym, co jest dla nas ważne, a zasada zwięzłości o zachowaniu umiaru w mówieniu. 
samorządu terytorialnego przebiega w bardzo zróżnicowany sposób. Budżety obywatelskie wprowadzane są w jednostkach samorządu terytorialnego w oparciu o artykuł 5a Ustawy o samorządzie gminnym, który wskazuje, że w wypadkach przewidzianych Ustawą oraz $w$ innych sprawach ważnych dla jednostki samorządu terytorialnego mogą być przeprowadzane konsultacje z mieszkańcami. Jednostki samorządu terytorialnego określają uchwałą rady lub zarządzeniem organu wykonawczego zasady i procedury postępowania przy realizacji budżetu obywatelskiego. Podkreślić należy jednak, że budżet obywatelski nie jest równoznaczny z konsultacjami społecznymi, gdyż nie są one wiążące dla władz samorządowych, a w przypadku budżetu obywatelskiego przyjmuje się, że władze samorządowe gwarantują mieszkańcom, że ich wola zostanie przez nie uszanowana i uwzględniona. Ta deklaracja władz samorządowych ma charakter umowy społecznej zawartej między władzą a społecznością lokalną. Projekty wybrane przez mieszkańców zostaną sfinansowane w kolejnym roku budżetowym. Podkreślić jednak trzeba, że jedyną sankcją, jaką mieszkańcy mogą nałożyć na władze samorządowe za niezrealizowanie projektów, jest niegłosowanie w kolejnych wyborach na dane władze.

Budowanie budżetu obywatelskiego odbywa się etapami. Pierwszym etapem opracowania budżetu obywatelskiego jest zapoznanie mieszkańców i użytkowników jednostki samorządu terytorialnego z wszystkich działaniami i dziedzinami, które może on obejmować. Elementami odróżniającymi tworzenie budżetu partycypacyjnego od innych form aktywności obywatelskich jest m.in. przeprowadzenie publicznej dyskusji, która odbywa się w toku jego przygotowania (etap drugi). W trakcie takich spotkań istnieje możliwość zadawania szeregu pytań odpowiednim ekspertom lub urzędnikom. Kolejnym, trzecim etapem jest zastosowanie mechanizmu głosowania, za pomocą którego uczestnicy wybierają i hierarchizują dyskutowane kategorie $\mathrm{z}$ podkreśleniem tych, którym nadawany jest najwyższy priorytet.

Utworzenie budżetu obywatelskiego $\mathrm{w}$ samorządzie wiąże się $\mathrm{z}$ daniem mieszkańcom możliwości decydowania o kwotach sięgających dziesiątek milionów złotych. Jednak w przeliczeniu do całości budżetu jednostek samorządu terytorialnego mieszkańcom pozostawia się jedynie od $0,5 \%$ do około $1 \%$ środków publicznych. Nie jest to, jak widać, bardzo dużo.

Dodatkowo w przygotowywanych zasadach i procedurach budżetów obywatelskich wprowadza się formy ograniczania katalogu zadań możliwych do sfinansowania. Taka sytuacja powoduje, że zmniejsza się zasięg odbiorców tego narzędzia.

W polskich samorządach dominuje zamknięty katalog podmiotów uprawnionych do zgłaszania przedsięwzięć do budżetu obywatelskiego. Są to głównie mieszkańcy, organizacje pozarządowe, organy jednostek pomocniczych samorządu terytorialnego (np. rady osiedli) oraz jednostki organizacyjne gminy. 
Zgłaszanie projektów do budżetu obywatelskiego odbywa się zwykle przy wykorzystaniu formularzy przygotowanych specjalnie do tego celu. Wypełnione formularze mieszkańcy przekazywali do urzędów. W większości zawierały one ustandaryzowane rubryki, w których powinny się pojawić informacje, takie jak nazwa i szczegółowy opis przedsięwzięcia, oszacowane koszty przedsięwzięcia. Zgłaszane wnioski były weryfikowane przez specjalnie powołane do tego celu komisje składające się z przedstawicieli administracji, przedstawicieli rady jednostki samorządu terytorialnego. Po pozytywnej weryfikacji projekty zostały poddane głosowaniu z wykorzystaniem następującego katalogu instrumentów:

a) kart do głosowania, które należało wrzucić do urny zlokalizowanej w konkretnym miejscu na terenie jednostki samorządu terytorialnego;

b) głosowania drogą elektroniczną przez wypełnianie specjalnych formularzy na stronie internetowej urzędu lub przez wysyłkę wypełnionej karty do głosowania na adres e-mailowy urzędu;

c) głosowania podczas zebrań mieszkańców;

d) wypełnianie karty do głosowania i wysyłanie drogą pocztową.

Warte podkreślenia jest jednak to, że w większości przypadków dostępne były jednocześnie różne formy głosowania.

Wiele polskich miast postanowiło włączyć obywateli w decydowanie o wydatkach miasta, jego nowych inwestycjach. Pośród nich znajdują się m.in.: Poznań, Elbląg, Gorzów Wielkopolski, Zielona Góra, Łódź czy Sopot (Kębłowski, 2013, s. 14-15). Prace nad łódzkim i poznańskim budżetem obywatelskim rozpoczęto w 2012 r., przeznaczając na ten cel $10 \mathrm{mln}$ złotych (około 0,4\% budżetu miasta Poznania) oraz $20 \mathrm{mln}$ złotych (około 0,6\% budżetu miasta Łodzi). Mieszkańcy w ramach tej inicjatywy mieli możliwość zgłaszania pomysłów inwestycji, które najbardziej odpowiadałyby ich potrzebom. W Poznaniu w 2013 r. zgłoszono 265 pomysłów na łączną kwotę 402,5 mln złotych. W Łodzi natomiast zgłoszono 908 wniosków na kwotę wielokrotnie przekraczającą budżet. Zebrane $\mathrm{w}$ ten sposób projekty poddano następnie weryfikacji przez wydziały merytoryczne urzędu miejskiego, w wyniku której określono listę projektów i zadań do głosowania. Merytoryczna kontrola zgłoszonych pomysłów odbyła się według kryteriów określonych przez poszczególne jednostki samorządu terytorialnego. Kolejnym etapem było głosowanie nad projektami, które przeszły pozytywnie weryfikację. W Łodzi na 759 projektów oddano prawie 130 tys. głosów. Do realizacji zostało zakwalifikowanych 109 projektów, które w większości udało się do końca 2014 r. zrealizować. W Poznaniu głosowaniu poddano 20 projektów. Ostatecznie zdecydowano o realizacji pięciu projektów (rozbudowie hospicjum, o budowie ciągu pieszo-rowerowego nad Wartą, ośrodka krótkiego pobytu dla osób niepełnosprawnych, drogi rowerowej oraz rodzinnego placu zabaw) (Instrumenty partycypacji spolecznej w teorii i praktyce, s. 287; Basaj, 2013, s. 9, 279-288). 


\subsubsection{Zalety i wady budżetu partycypacyjnego}

Budżet obywatelski jako jedna z form partycypacji społecznej pozytywnie oddziałuje na społeczność lokalną, choć coraz częściej pojawia się konieczność wprowadzenia kolejnych rozwiązań regulujących wybrane kwestie, aby zabezpieczyć ten instrument przed możliwością nadużyć. Jednym z bezpośrednich skutków realizacji działań partycypacyjnych w ramach budżetu obywatelskiego jest rozdzielenie ograniczonych środków finansowych adekwatne do rzeczywistych potrzeb mieszkańców. Kolejnym jest budowanie zaufania do władz lokalnych, poczucia przejrzystości podejmowanych decyzji oraz tworzenie legitymizacji dla dalszych działań związanych z wydatkami (Pyka, 2011, s. 47-58).

Ponadto budżet partycypacyjny swoją skuteczność zawdzięcza elastyczności. Szereg organizowanych otwartych spotkań dla mieszkańców, których celem była edukacja, informowanie oraz wspólne opracowanie zasad i procedur dla planów budżetowych podnosi efektywność realizowanej dotąd polityki miejskiej.

Kolejnymi zaletami budżetu obywatelskiego są: promocja działań innowacyjnych i przedsiębiorczości wśród mieszkańców, podniesienie wiedzy mieszkańców o funkcjonowaniu budżetu, możliwość uczestniczenia w podejmowaniu trudnych i kontrowersyjnych decyzji, związanych m.in. z cięciami budżetowymi. Przy wykorzystaniu tego instrumentu wzrasta również poziom decentralizacji władzy, a także budowane i wzmacniane jest zaufanie pomiędzy mieszkańcami a władzami lokalnymi i jej przedstawicielami oraz następuje wzrost legitymizacji działań władzy i prowadzonej polityki miejskiej wśród mieszkańców i użytkowników jednostki samorządu terytorialnego (Basaj, 2011). Następuje również integracja mieszkańców wokół ważnych dla nich kwestii, a także lepsze poznanie ich potrzeb, opinii i nowych rozwiązań.

\subsection{Inicjatywa lokalna}

Jedną z najnowszych i wciąż mało popularnych form partycypacji społecznej, która zapewnia mieszkańcom nie tylko udział w procesie decyzyjnym, ale także realizacyjnym, jest inicjatywa lokalna. To nowa forma realizacji zadań publicznych wykonywanych przez jednostkę samorządu terytorialnego we współpracy z mieszkańcami. Stąd też literatura przedmiotu wskazuje, że inicjatywa lokalna łączy się z dwoma wymiarami zaangażowania społeczności lokalnej w rozwój ich wspólnoty terytorialnej. Pierwszym wymiarem jest partycypacja, czyli współudział mieszkańców w zarządzeniu lokalną wspólnotą, drugim wymiarem - aktywność społeczności lokalnej w realizacji zadań publicznych. Jak pokazują badania realizowane w ostatnich latach (projekt „Decydujmy Razem”), zarówno 
z partycypacją, jak i z realizacją zadań publicznych mamy w Polsce spory problem. Współpraca władz lokalnych z mieszkańcami ogranicza się głównie do najmniej wymagających form partycypacji, czyli do informowania i konsultowania. Od dziesiątków lat największe poparcie przedstawicieli władz lokalnych mają sposoby zarządzania jednostkami samorządowymi, które polegają głównie na podejmowaniu decyzji przez decydentów oraz na informowaniu o nich społeczności lokalnej. Jak pokazują badania, mieszkańcy jednostek samorządu terytorialnego w Polsce rzadko także uczestniczą w życiu publicznym. Wśród najpowszechniejszych form partycypacji społecznej dominują te o charakterze biernym i są one skoncentrowane głównie na poszukiwaniu informacji na temat decyzji podejmowanych przez władze samorządowe (Olech, Sobiesiak-Penszko, 3/2013, s. 1-29; Czarkowska, Domagała, Jachimowicz, 2013, s. 2).

Jak funkcjonuje i na czym polega inicjatywa lokalna oraz kto może z niej korzystać?

Wnioski o inicjatywę lokalną mogą zgłaszać mieszkańcy (pojedyncze osoby lub grupy) oraz organizacje pozarządowe, na terenie jednostki administracyjnej, w której mieszkają lub mają siedzibę. Wnioski składa się do odpowiednich organów wykonawczych administracji samorządowej, tj. do wójta, burmistrza lub prezydenta, a także zarządu powiatu lub województwa. Dotyczą one ważnych dla mieszkańców kwestii związanych z funkcjonowaniem jednostek samorządu terytorialnego i świadczonych przez nie usług publicznych: np. budowy albo remontu dróg, sieci kanalizacyjnej, wodociągowej, działalności kulturalnej, edukacyjnej, oświatowej, sportowej i turystycznej, promocji i organizacji wolontariatu, ochrony przyrody oraz porządku i bezpieczeństwa publicznego (Ustawa o działalności pożytku publicznego, s. 14).

Inicjatywę lokalną wprowadziła Ustawa z 24 kwietnia 2003 r. o działalności pożytku publicznego i wolontariacie jako nowe narzędzie realizacji zadań. Ustawa nie reguluje jednak zasad jej funkcjonowania w jednostkach samorządu terytorialnego. Zgodnie z art. 19c (Ustawa o działalności pożytku publicznego i wolontariacie, Dz. U. 2003, nr 96, poz. 873) to organ stanowiący jednostki samorządu terytorialnego (rada gminy, powiatu, województwa) samodzielnie określa tryb i szczegółowe kryteria oceny wniosków o realizację zadania publicznego w ramach inicjatywy lokalnej, stąd też rozwiązania przyjmowane w poszczególnych jednostkach samorządu różnią się od siebie. Takie rozwiązanie pozwala dostosować zasady, tryb i kryteria oceny do specyfiki poszczególnych wspólnot terytorialnych. Procedura składania wniosków w ramach inicjatywy lokalnej nie jest $\mathrm{z}$ reguły skomplikowana. Wnioski składane są $\mathrm{w}$ trybie procedur kodeksu postępowania administracyjnego (KPA).

Organ wykonawczy następnie ocenia zasadność złożonego wniosku i na podstawie opracowanych kryteriów decyduje o jego przyjęciu do realizacji lub odrzuceniu. Najważniejszym elementem wniosku i możliwości jego realizacji jest 
deklarowany w ramach inicjatywy lokalnej udział mieszkańców w jego realizacji. To oznacza, że mieszkańcy nie tylko przedstawiają organowi władzy wykonawczej konkretny pomysł do realizacji, ale także deklarują współudział w jego realizacji. Deklarowany udział mieszkańców zwykle dotyczy świadczenia pracy społecznej, świadczeń pieniężnych lub rzeczowych. Jednym z najważniejszych elementów oceny tych wniosków jest wkład pracy społecznej deklarowany przez mieszkańców.

$\mathrm{Na}$ czas określony, tj. na czas realizacji przedsięwzięcia, organ wykonawczy jednostki samorządu terytorialnego zawiera umowę z wnioskodawcą o wykonanie inicjatywy lokalnej. Wnioskodawca w myśl przepisów ustawy na czas trwania umowy może otrzymać od jednostki samorządu terytorialnego rzeczy konieczne do wykonania inicjatywy lokalnej. Dodatkowym udogodnieniem dla mieszkańców, przewidzianym przez ustawodawcę, jest pomoc jednostki samorządu terytorialnego w zakresie opracowania harmonogramu i kosztorysu. Organ wykonawczy jednostki samorządu terytorialnego wspólnie z wnioskodawcą opracowuje dokumenty niezbędne do przeprowadzenia inicjatywy lokalnej, w tym harmonogram i kosztorys (Ustawa o działalności pożytku publicznego, s. 14).

Ciekawym rozwiązaniem wskazanym w ustawie jest konieczność podpisania umowy między jednostką samorządu terytorialnego a wykonawcą (mieszkańcy, organizacje pozarządowe). W zakresie nieuregulowanym w ustawie do umowy stosuje się odpowiednio przepisy kodeksu cywilnego. Taki zapis skutkuje tym, że mieszkańcy mogą dochodzić odszkodowań od jednostki samorządu terytorialnego, gdy ten nie zrealizował inicjatywy lokalnej.

Głównym celem inicjatywy lokalnej jest zwiększenie udziału mieszkańców w życiu wspólnoty terytorialnej poprzez ich zaangażowanie w podejmowanie decyzji oraz obecność w konkretnej realizacji zadania.

Inicjatywa lokalna jest instrumentem, który może bezpośrednio rozpoczynać realizację zadań publicznych zaspokajających konkretne, zidentyfikowane potrzeby mieszkańców. Jednak przy tej okazji pojawiają się głosy próbujące kwestionować to narzędzie i możliwości jego wykorzystania, bo przecież to niby nic nowego. A jednak w ustawie o działalności pożytku publicznego i wolontariacie podkreśla się, że jest to forma współpracy jednostek samorządu terytorialnego z ich mieszkańcami w celu wspólnego realizowania dla tej społeczności zadań publicznych. Takie sformułowanie wskazuje role, jakie władze samorządowe i mieszkańcy odgrywają przy realizacji tych zadań. Podkreśla się tutaj partnerską współpracę, która także $\mathrm{w}$ umowie zawieranej pomiędzy stronami określa pewne prawa i zobowiązania nie tylko względem społeczności lokalnej, dla której realizowane będą usługi publiczne, ale także względem siebie nawzajem jako partnerów.

Inicjatywa lokalna służy również realizacji zadań publicznych przez podmioty, które nie posiadają osobowości prawnej. Do takich podmiotów zaliczyć można np. koła gospodyń wiejskich, kluby seniora. Brak osobowości prawnej wyklucza takie podmioty z możliwości otrzymania dotacji w drodze konkursu, a to narzędzie daje szansę realizacji zadań. 
Jedną z głównych barier rozwoju inicjatywy lokalnej są środki finansowe przeznaczane przez jednostkę samorządu terytorialnego na proponowane przez mieszkańców przedsięwzięcia. Trudna sytuacja finansowa samorządów nie skłania do przesuwania środków finansowych na tego typu inicjatywy, szczególnie gdy skala oddziaływania tych przedsięwzięć w oczach przedstawicieli samorządów jest niewielka.

Środki finansowe na realizację inicjatywy lokalnej w polskich samorządach wyodrębnia się w dwojaki sposób:

1) Wydzielenie puli środków z budżetu jednostki samorządu terytorialnego i przypisanie ich na współfinansowanie działań w ramach inicjatywy lokalnej. Odbywa się to najczęściej w formie rezerwy celowej, która rozwiązywana jest przez organ wykonawczy, gdy zostanie podjęta decyzja o współrealizacji inicjatywy lokalnej przez właściwe komórki organizacyjne samorządu. Ten sposób zapewnia więc, że mieszkańcy mogą składać wnioski w każdej chwili, a także dużą elastyczność w działaniu samorządu.

2) Włączenie przedsięwzięć związanych $z$ realizacją inicjatywy lokalnej w budżet poszczególnych komórek jednostek organizacyjnych samorządu jako formy realizacji zadania publicznego (Czarkowska, Domagała, Jachimowicz, 2013, s. 15-17).

Szczególną wartością inicjatywy lokalnej jest wzmacnianie zaangażowania mieszkańców przy realizacji zadań, które pozostają w kompetencjach samorządu. Jest ona także szansą na zwiększenie aktywności społeczności lokalnej w rozwiązywaniu lokalnych problemów, a także narzędziem efektywnego jej wsparcia. Ponadto inicjatywa lokalna posiada konkretny wymiar ekonomiczny, gdyż mieszkańcy mają możliwość partycypowania w realizacji zadania publicznego m.in. poprzez pokrycie części jego kosztów. Podkreślić należy, że inicjatywa lokalna nie jest nowym zadaniem jednostek samorządu terytorialnego. Jest to nowa forma realizacji zadań samorządu. Nie jest to także nowa pula środków finansowych do wydatkowania na te zadania, a inny sposób ich wydatkowania.

\section{Bariery wykorzystania instrumentów partycypacyjnych w zarządzaniu jednostkami samorządu terytorialnego}

Partycypacja społeczna ma niewątpliwie wiele zalet. Jednak mimo bardzo korzystnego wpływu wykorzystania instrumentów partycypacyjnych w zarządzaniu jednostkami samorządu terytorialnego istnieje nadal wiele problemów, które wymagają pilnego rozwiązania. Funkcjonują liczne bariery utrudniające zastosowanie instrumentów partycypacyjnych. Są to bariery wynikające z różnych powodów znajdujących się zarówno po stronie samorządowej, jak i po stronie społeczności lokalnej. 
Mieszkańcy nie uczestniczą w podejmowaniu publicznych decyzji z wielu powodów. Wśród nich można wymienić m.in. brak świadomości i kompetencji mieszkańców w zakresie funkcjonowania samorządu terytorialnego. Wiele procesów, procedur jest niezrozumiałych, a przez to sprawiają wrażenie skomplikowanych. Wciąż przebieg procesu partycypacji nie odpowiada realnym potrzebom społeczności lokalnej, która gotowa jest zaangażować się mocniej i bardziej efektywnie we wstępnej fazie planowania i przygotowywania rozwiązań. Władze samorządowe często nie traktują mieszkańców jako pełnoprawnych uczestników procesu decyzyjnego, pozwalając im jedynie wypowiedzieć się w temacie gotowego już projektu, oczekując przy tym pełnej aprobaty zaproponowanych rozwiązań. Tworzy się w ten sposób niedemokratyczny klimat funkcjonowania i zarządzania jednostkami samorządu terytorialnego. Takie zachowania zniechęcają do interesowania się i angażowania się mieszkańców w sprawy publiczne. Błędy w organizacji i wykorzystaniu instrumentów partycypacyjnych skutkują poczuciem niemożności i prowadzą do wycofania się z procesu decyzyjnego i prowadzenia społecznej kontroli władz samorządowych.

W polskich samorządach wciąż pokutuje przekonanie, że co nie jest zapisane w prawie to jest niemożliwe, więc niejednokrotnie trudno przekonać pracowników administracji samorządowej do słuszności wykorzystania nowych instrumentów partycypacyjnych.

Ze strony społeczności lokalnej również spotkać można bariery w wykorzystaniu instrumentów partycypacyjnych. Podmioty społeczne niejednokrotnie mylą konsultacje z negocjacjami czy też możliwością zawierania porozumień, co nasila niechęć do udziału w procesie partycypacji społecznej. Wymienione bariery i problemy trudno będzie wyeliminować w najbliższych latach. To proces długotrwały, jednak nabiera w ostatnich latach większego tempa. Problemy te trudno będzie wyeliminować wyłącznie za pomocą instrumentów prawno-legislacyjnych. Wydaje się, że pozytywne zmiany, jakie zachodzą, są wynikiem praktyki i wzajemnego uczenia się współpracy przez wszystkie strony tego procesu.

\section{Podsumowanie}

W zarządzaniu jednostkami samorządu terytorialnego stosuje się metody i techniki partycypacyjne coraz bardziej angażujące członków społeczności lokalnych. Proces ten postępuje małymi krokami, ale paleta wykorzystywanych instrumentów partycypacyjnych się rozszerza. Wykorzystywane są coraz bardziej elastyczne i interaktywne metody angażujące mieszkańców, co sprzyja kreatywności, wychodzeniu poza utarte schematy myślenia, a także wypracowaniu nowych i niekonwencjonalnych rozwiązań odpowiadających na potrzeby społeczności lokalnej. Angażowanie w procesy decyzyjne sprzyja identyfikacji uczestników z tym procesem, projektami przygotowywanymi dopiero do reali- 
zacji, a także z ich rezultatami. Instrumenty partycypacyjne uczą uczestników tego procesu wspólnego wypracowywania sposobów wyjścia z trudnych sytuacji i schematów, a także kreatywnego rozwiązywania problemów. Wykorzystanie nowoczesnych instrumentów partycypacyjnych sprzyja wzajemnemu poznawaniu się partnerów, przełamywaniu barier i nieufności przy zgłaszaniu postulatów i nowych rozwiązań, sprzyja budowaniu klimatu partnerskiej współpracy. Budowane są dzięki temu silne więzi i relacje pomiędzy przedstawicielami różnych środowisk, różnych instytucji.

Jednostki samorządu terytorialnego mają dużą dowolność w stanowieniu o sposobie, zasadach i trybie uczestnictwa mieszkańców w uchwalaniu prawa lokalnego i polityk publicznych. Polskie prawo z niewieloma wyjątkami pozostawia dobrowolność i dowolność samorządom w tej kwestii. Niestety, jak pokazują wyniki wielu realizowanych w ostatnich latach badań, nie przekłada się to na znaczący wzrost wykorzystania instrumentów partycypacyjnych i duże zaangażowanie społeczności lokalnych w procesy decyzyjne. Widoczne jest także duże zróżnicowanie jednostek samorządu terytorialnego w tej kwestii. Wiele samorządów próbuje od lat zaangażować mieszkańców i wspólnie współdecydować o ważnych dla wspólnoty sprawach, ale wciąż wiele jednostek samorządowych w Polsce nie ma jeszcze świadomości korzyści płynących ze współpracy ze społecznością lokalną, a co za tym idzie nie są zainteresowane czy też wręcz boją się zaprosić mieszkańców do dialogu.

Istnieje wiele istotnych barier i problemów związanych z partycypacją społeczną w zarządzaniu jednostkami samorządu terytorialnego, które mimo wysiłku wielu pracowników samorządowych, mieszkańców czy też przedstawicieli organizacji pozarządowych trudno będzie wyeliminować w najbliższych latach. Proces partycypacji związany z angażowaniem społeczności lokalnej w życie społeczno-gospodarcze wspólnoty terytorialnej jest długotrwały, jednak nabiera w ostatnich latach większego tempa. Problemy trudno będzie wyeliminować wyłącznie za pomocą instrumentów prawno-legislacyjnych. Wydaje się, że pozytywne zmiany, jakie zachodzą i będą zachodzić, są wynikiem praktyki i wzajemnego uczenia się współpracy przez wszystkie zainteresowane strony tego złożonego procesu.

\section{Bibliografia}

Badanie stanu partycypacji publicznej, Instytut Spraw Publicznych, projekt „Decydujmy razem”, 2011, 2012.

Basaj M. (2013), Instrumenty partycypacji społecznej w teorii i praktyce zintegrowanego zarzadzania miastem, Acta Universitatis Nicolai Copernici, z. 413, Toruń.

Citizens Jury Handbook (2004), The Jefferson Center.

Czarkowska A., Domagała Ł. i Jachimowicz A. (red.) (2013), Inicjatywa lokalna krok po kroku, Sieć Wspierania Organizacji Pozarządowych SPLOT, Warszawa. 
Długosz D., Wygnański J. (2005), Obywatele współdecydują, Stowarzyszenie na rzecz Forum Inicjatyw Pozarządowych, Warszawa.

Dyrektywa 2003/35/WE Parlamentu Europejskiego i Rady z dnia 26 maja 2003 r. przewidująca udział społeczeństwa w odniesieniu do sporządzania niektórych planów i programów w zakresie środowiska oraz zmieniająca w odniesieniu do udziału społeczeństwa i dostępu do wymiaru sprawiedliwości.

Dyrektywa Rady 96/61/WE z dnia 24 września 1996 r. dotycząca zintegrowanego zapobiegania zanieczyszczeniom i ich kontroli.

Dyrektywa Rady z dnia 27 czerwca 1985 r. w sprawie oceny skutków wywieranych przez niektóre przedsięwzięcia publiczne i prywatne na środowisko naturalne 85/337/EWG, Dz.U.UE.L.85.175.440.

Europejska Karta Samorządu Lokalnego, Dz. U. 1994, nr 124, poz. 607.

Gawroński H. (2010), Zarządzanie strategiczne w samorządzie lokalnym, Oficyna Wolter Kluwer Business, Warszawa.

Górski R. (2005), Przewodnik po demokracji uczestniczacej (partycypacyjnej), Oficyna Wydawnicza Bractwa „Trójka”, Poznań-Kraków.

http://budzet.dlalodzi.info/

http://partycypacjaobywatelska.pl/

Jak prowadzić konsultacje spoleczne w samorzadach? Zasady i najlepsze praktyki wspótpracy samorzadów z przedstawicielami społeczności lokalnych. Przewodnik dla samorząów (2010), Fundacja Rozwoju Demokracji Lokalnej, Warszawa.

Kębłowski W. (2013), Budżet partycypacyjny. Krótka instrukcja obsługi, Instytut Obywatelski, Warszawa.

Komunikat Komisji Europejskiej Główne zasady i minimalne standardy konsultacji zainteresowanych stron przez Komisję Europejską, COM/2002/0704.

Konstytucja Rzeczypospolitej Polskiej, Dz. U. 1997, nr 78, poz. 483.

Konwencja o Dostępie do Informacji, Udziale Społeczeństwa w Podejmowaniu Decyzji oraz Dostępie do Sprawiedliwości w Sprawach Środowiska, Dz. U. 2003, nr 78, poz. 706.

Kot J. (2003), Zarzadzanie rozwojem gmin a praktyka planowania strategicznego, Wydawnictwo Uniwersytetu Łódzkiego, Łódź.

Kraszewski D., Mojkowski K. (2014), Budżet obywatelski w Polsce, Fundacja im. Stefana Batorego, Warszawa.

Krzyżanowska Ł., Faciejew Ł. (2009), Partycypacja obywatelska w Polsce, Fundacja im. Stefana Batorego, Warszawa.

Lindsey G., et al., A handbook for planning and conducting charrettes for high-performance projects, National Renewable Energy Laboratory.

Markowski T., Marszał T. (2005), Funkcje i zarządzanie obszarami metropolitalnymi, „Samorząd Terytorialny", nr 7/8, Warszawa.

Markus M. (2013), Koszmar partycypacji, Fundacja Bęc Zmiana, Warszawa.

Olech A. (2013), Kiedy mieszkańcy uczestnicza w podejmowaniu decyzji, [w:] idem, Przepis na uczestnictwo. Diagnoza partycypacji publicznej w Polsce, t. II, Instytut Spraw Publicznych, Warszawa.

Olech A. (2011), Modele partycypacji publicznej - teoria i praktyka społeczna, [w:] A. Olech (red.), Partycypacja publiczna. O uczestnictwie obywateli w życiu wspólnoty lokalnej, Instytut Spraw Publicznych, Warszawa.

Olech A. (2013), Modele partycypacji publicznej w Polsce, [w:] idem, Przepis na uczestnictwo. Diagnoza partycypacji publicznej w Polsce, t. II, Instytut Spraw Publicznych, Warszawa.

Olech A., Sobiesiak-Penszko P. (2013), Partycypacja społeczna w Polsce. Diagnoza i rekomendacje, „Analizy i Opinie”, 3/2013. 
Podręcznik zarządzania partycypacyjnego (2013), Fundacja Inicjatyw Menedżerskich.

Projekt Społeczny 2012, http://www.ps2012.p1/

Przybylska A. (2014), Jaka przyszłość maja w Polsce deliberatywne formy konsultacji społecznych?, [w:] A. Przybylska, A. Giza (red.), Partycypacja obywatelska. Od teorii do praktyki społecznej, Wydawnictwo Naukowe Scholar, Warszawa.

Pyka M. (2011), Poradnik „Dobrych praktyk konsultacji społecznych”, Sieć Wspierania Organizacji Pozarządowych SPLOT, Warszawa.

Roberts N. C. (2008), Direct Citizen Participation: Challenges and Dillemas, [w:] N. C. Roberts, M. E. Sharp (red.), The Age of Direct Citizen Participation, Armon, New York.

Rozmowy w Kawiarence. Przewodnik krok po kroku, jak z rozmowy zrobić narzędzie (2012), Fundacja Inicjatyw Społeczno-Ekonomicznych, Warszawa.

Sakowicz M. (2007), Modernizacja samorządu terytorialnego, Szkoła Główna Handlowa, Warszawa.

Siedem zasad konsultacji (2013), Ministerstwo Administracji i Cyfryzacji, Warszawa.

Słownik języka polskiego, Wydawnictwo Naukowe PWN, www.sjp.pwn.pl

Swianiewicz P. (2008), Rola społeczności w koncepcjach polityki lokalnej, [w:] E. Leś (red.), Gospodarka społeczna i przedsiębiorstwo spoleczne. Wprowadzenie do problematyki, Wydawnictwo Uniwersytetu Warszawskiego, Warszawa.

Swianiewicz P., Klimska U., Mielczarek A. (2004), Nierówne koalicje - liderzy miejscy w poszukiwaniu nowego modelu zarządzania rozwojem, Wydawnictwo Naukowe „Scholar”, Warszawa.

Ustawa z dnia 24 kwietnia 2003 r. o działalności pożytku publicznego i wolontariacie, Dz. U. 2003, nr 96, poz. 873.

Ustawa z dnia 12 marca 2004 r. o pomocy społecznej, Dz. U. 2004, nr 64, poz. 593.

Ustawa z dnia 20 kwietnia 2004 r. o promocji zatrudnienia i instytucjach rynku pracy, Dz. U. 2004, nr 99, poz. 1001.

Ustawa z dnia 27 marca 2003 r. o planowaniu i zagospodarowaniu przestrzennym, Dz. U. 2003, nr 80, poz. 717 .

Ustawa z dnia 3 października 2008 r. o udostępnianiu informacji o środowisku i jego ochronie, udziale społeczeństwa w ochronie środowiska oraz o ocenach oddziaływania na środowisko, Dz. U. 2008, nr 199, poz. 1227.

Ustawa z dnia 5 czerwca 1998 r. o samorządzie powiatowym, Dz. U. 1998, nr 91, poz. 578.

Ustawa z dnia 5 czerwca 1998 r. o samorządzie województwa, Dz. U. 1998, nr 91, poz. 576.

Ustawa z dnia 6 grudnia 2006 r. o zasadach prowadzenia polityki rozwoju, Dz. U. 2006, nr 227, poz. 1658.

Ustawa z dnia 6 lipca 2001 r. o Trójstronnej Komisji do Spraw Społeczno-Gospodarczych i wojewódzkich komisjach dialogu społecznego, Dz. U. 2001, nr 100, poz. 1080.

Ustawa z dnia 8 marca 1990 r. o samorządzie gminnym, Dz. U. 1990, nr 16, poz. 95.

White Paper: European Governance (2001), COM(2001)428.

Zychowicz Z. (red.) (2011), Przeprowadzenie konsultacji społecznych w samorzadzie, Instytut Rozwoju Regionalnego, Szczecin.

\section{PARTICIPATORY INSTRUMENTS FOR THE MANAGEMENT OF LOCAL GOVERNMENT UNITS}

\section{(Summary)}

Local government is one of the important elements of the democratic system, which presently assumes closeness between the local government and the community. Local authorities are therefore an institution responsible for the participatory management and coordination of public policies in local government units. 
The publication presents the issues of public participation in the management of local government units related to its essence, form, legal regulations and barriers. An important part of the chapter is to present the theory and practice of selected modern participatory instruments, including principles and standards of public consultation, participatory budgeting and local initiatives. The chapter ends with the identification of barriers to the use of participatory instruments in the management of local government units.

Key words: social participation, public consultation, participation models, participation barriers, local government. 